University of Wollongong

Research Online

Faculty of Business - Papers (Archive)

Faculty of Business and Law

$1-1-2017$

Political connections and corporate investments: Evidence from the recent anti-corruption campaign in China

Xiaofei Pan

University of Wollongong, xpan@uow.edu.au

Gary G. Tian

Macquarie University, gtian@uow.edu.au

Follow this and additional works at: https://ro.uow.edu.au/buspapers

Part of the Business Commons

Research Online is the open access institutional repository for the University of Wollongong. For further information contact the UOW Library: research-pubs@uow.edu.au 


\title{
Political connections and corporate investments: Evidence from the recent anti- corruption campaign in China
}

\author{
Abstract \\ Taking advantage of corruption scandals in China, we construct a natural experiment and identify the \\ ousting of corrupt politicians, and firms connected with them through bribery and personal relationships \\ (event firms). We find that the investment expenditure of event firms declines significantly after the \\ ousting of the politicians compared with that of non-event firms, especially for non-SOEs. We also find \\ that, after the ousting of the politicians, investment efficiency improves for event SOEs, but declines for \\ event non-SOEs, compared with their non-event counterparts. We also document that the ousting of the \\ politicians influences firm investment decisions more after the recent anti-corruption campaign, for \\ bribing firms and for firms in more corrupt regions. These results are robust to alternative measurements \\ of key variables and specifications.

\section{Disciplines \\ Business}

\section{Publication Details} \\ Pan, X. \& Tian, G. (2017). Political connections and corporate investments: Evidence from the recent anti- \\ corruption campaign in China. Journal of Banking and Finance, Online First 1-15.
}




\title{
Political connections and corporate investments: Evidence from the recent anti-corruption campaign in China
}

\author{
Xiaofei $\operatorname{Pan}^{1}$, Gary $\operatorname{Tian}^{2 *}$ \\ ${ }^{1}$ School of Accounting, Economics and Finance, University of Wollongong, Australia \\ ${ }^{2}$ Department of Applied Finance and Actuarial Studies, Macquarie University, Australia
}

\begin{abstract}
Taking advantage of corruption scandals in China, we construct a natural experiment and identify the ousting of corrupt politicians, and firms connected with them through bribery and personal relationships (event firms). We find that the investment expenditure of event firms declines significantly after the ousting of the politicians compared with that of non-event firms, especially for non-SOEs. We also find that, after the ousting of the politicians, investment efficiency improves for event SOEs, but declines for event non-SOEs, compared with their non-event counterparts. We also document that the ousting of the politicians influences firm investment decisions more after the recent anti-corruption campaign, for bribing firms and for firms in more corrupt regions. These results are robust to alternative measurements of key variables and specifications.
\end{abstract}

Key words: Corruption, rent seeking, investment decisions, political capital JEL: G31, G34, P26

\footnotetext{
* Gary Tian is corresponding author; his email is gary.tian@mq.edu.au.Xiaofei Pan’s email is xpan@uow.edu.au.
} 


\section{Introduction}

The existing literature has documented that political connections provide valuable resources for firms, in terms of easy access to external finance and more relationship-based contracts (Claessens et al., 2008; Houston et al., 2014; Piotroski and Zhang, 2014), which in turn can affect firms' investment decisions (Lang et al., 1996; Aivazian et al., 2005). On the one hand, political connections can help mitigate the problems caused by financial constraints and increase the capital available for firm investment activities, which addresses the problem of under-investment (Xu et al., 2011). However, access to more external capital derived from political connections may also encourage firms to engage in sub-optimal investments. On the other hand, firms' political connections may indicate severe government intervention and distort firms' ultimate objectives. Thus, to achieve social or political objectives favoured by the government, firms may be forced to invest in unprofitable but politically favoured projects, which in turn leads to investment inefficiency (Chen et al., 2011b). Therefore, the influence of political connections on firm investment decisions is mixed and needs further exploration.

The existing studies usually examine the influence of political connections using a static research setup, namely comparing the cross-sectional variation of economic outcomes between firms with and without political connections. However, it is unclear how these economic outcomes respond to a change in political connections when firms are associated with an ousted official. The answer to this issue is of particular importance, as changes in political connections are likely to affect the incentives and actions of firms, and provide greater insight into the dynamic responses that firms have in reacting to shifts in the political regime. In this study, we take advantage of corruption scandals in China to examine how political capital established through corruption shapes corporate investment decisions. Specifically, we take advantage of ongoing corruption scandals and the recent anti-corruption campaign initiated in China to construct a natural experiment that identifies the termination of political ties. The identification of termination of political ties may alleviate the endogeneity issue to some extent. Although there is only one ruling party under the current Chinese political system, several different political cliques co-exist and compete fiercely with each other. Such scandals, which lead to the ousting of high-level corrupt bureaucrats, are commonly used by one clique when attempting to eliminate a competing clique (Hung et al., 2015). These scandals, therefore, are non-systemic and mainly driven by political factors, and they are unlikely to be foreseen by the market (Fan et al., 2008). To conduct an empirical 
analysis at the firm level, we identify firms that have been involved in these scandals and experienced the termination of political ties (termed event firms). Specifically, these event firms are those firms whose manager/director either bribed corrupt bureaucrats (bribing firms) or was connected with corrupt bureaucrats through personal relationship (connected firms) ${ }^{1}$. Therefore, we explicitly examine how corporate investment decisions respond to the termination of political ties, which allows us to identify the causal effect of political connections established through corruption on corporate investment decision.

The Chinese market is also a convenient and appropriate setting for the following reasons. Firstly, the Chinese economy is dominated by the government, which maintains control over key resources and decides on the allocation of resources. This environment directly results in the availability of huge economic rents, so that firms/individuals have strong incentives to bribe government officers to establish a close relationship with the government, in exchange for the creation and allocation of rents and government protection (Cai et al., 2011; Chen et al., 2011a). However, existing studies put forward two views, finding that corruption can either 'sand' or 'grease' the wheel of the economic growth (Shleifer and Vishny, 1993; Aidt et al., 2008). Based on these mixed results, the influence of political connections formed through corruption remains an empirical question.

Secondly, the co-existence of both state-owned enterprises (SOEs) and non-SOEs provides another unique institutional environment for examining the influence of political connections on corporate investment decisions. On the one hand, SOEs are controlled by the government, and thus are naturally connected with the government; so that their political connections may not provide additional benefits for SOEs. On the other hand, non-SOEs have incentives to establish political connections and take advantage of these connections; thus, political connections have been documented to be valuable for non-SOEs in areas such as financing and investment.

Consistent with our predictions, our empirical results show that investment expenditures made by event firms decreased more significantly relative to non-event firms, following the ousting of corrupt government officers; and that this is more pronounced for non-SOEs. We also find that, following the ousting of corrupt officers, the investment efficiency of event SOEs is rectified and improves significantly relative to that of non-event SOEs; while the investment efficiency of event non-SOEs deteriorates significantly more than that of non-

\footnotetext{
${ }^{1}$ An example of a bribing firm is $\mathrm{Zi}$ Xin Yao Ye (Stock code: 002118), and the corrupt bureaucrat is Mr Tian Xueren, the former vice-governor of Jilin Province, who was arrested in July 2012. During his term of office from 1995 to 2011, Mr Tian received a large bribe from the Chairman of Zi Xin Yao Ye, Mr Guo Chunsheng, which amounted to about 12.17 million RMB.
} 
event non-SOEs. These results are robust to alternative measurement of key variables, alternative explanations, alternative specifications, and alternative samples.

We also document that these results are more pronounced after the recent anti-corruption campaign, for bribing firms and for firms in more corrupt regions. Our further analysis, on the change of firm performance, managerial pay-performance relationship and perks, and stock market reactions, provides additional evidence to support our arguments and main hypotheses.

However, some caution is needed when interpreting our results. One potential concern is that changes in corporate investment decisions may only be visible over longer horizons. Because of limitations on the availability of data, we are unable to collect corporate investment information over long horizons for particular events (those occurring after 2013).

Our study contributes to the literature on political connections in several ways. Firstly, from the empirical perspective, we improve the traditional measurements of political connections used by most existing studies, which define political connections as having executives with previous working experience in governments: our politically connected firms (those event firms we defined earlier) include those firms that pay bribes to government officers and executives who have personal relationships with government officers. Our measurements are more objective, in identifying whether a connection between firms and politicians exists and whether this connection is exploited to extract rents. Secondly, the economic implications of political connections have been examined extensively, albeit with mixed evidence. In particular, political connections may increase firm value/performance (Claessens et al., 2008; Goldman et al., 2009; Wu et al., 2012), through easy access to external finance at a lower cost (Leuz and Oberholzer-Gee, 2006; Cleassens et al., 2008; Li et al., 2008; Houston et al., 2014; Piotroski and Zhang, 2014); while it has also been documented that they are associated with lower performance (Fan et al., 2007; Faccio, 2010) and higher interest rates (Bliss and Gul, 2012). Our study proposes that corporate investment is the channel through which political connections can affect firm performance; and that this depends heavily on the type of ultimate owner and potential costs incurred through rent seeking.

This study also contributes to the literature on corruption and rent seeking. Corruption is a global phenomenon and prevalent in forming political connections. Some studies contend that corruption is the main obstacle to economic development (Gaviria, 2002; Asiedu and Freeman, 2009); while others argue that corruption is less detrimental in environments with ineffective institutions (Meon and Weill, 2010; Cai et al., 2011). Our investigation 
complements the notion that corruption can either hinder or facilitate economic development. In particular, private benefits from bribing government officers are consumed by SOE managers for their personal objectives, which incurs substantial costs and reduces investment efficiency and firm performance. However, benefits for shareholders from bribery may outweigh the cost of bribery in non-SOEs, which improves investment efficiency and firm performance. Our findings are also consistent with the broad range of economic literature regarding the role played by political rent seeking in explaining firm behaviour and growth (Morck et al., 2005).

Moreover, despite the importance of the corruption effect at the firm level reported by several international surveys ${ }^{2}$, most academic studies typically take the perspective of data analysis at the country level (Mauro, 1995; Meon and Sekkat, 2005). By exploiting firm-level data, we usefully expand the evidence on the effect of corruption on corporate investment decisions, which complements previous studies.

The remainder of this paper proceeds as follows. Section 2 describes the corruption events and recent anti-corruption campaign, and the economic environment surrounding the corruption events. Section 3 discusses causal effects of identifying political connections, elaborates the construction of our sample firms, as well as control firms, assembles the empirical data, and introduces our empirical models. Section 4 presents the results of our analysis. Section 5 concludes.

\section{Institutional background and hypothesis development}

\subsection{Corruption and the anti-corruption campaign in China}

Corruption is acknowledged to be an international phenomenon, especially in emerging markets with underdeveloped financial systems, weak legal protection of investors, and severe government intervention. Shleifer and Vishny (1993) argue that the structure of government institutions and the political process are very important determinants of the level of corruption. In particular, weak governments that do not effectively control their agencies experience very high levels of corruption. International evidence confirms that political decentralization could impede coordination and exacerbate incentives for officials at various levels to 'overgraze' the common bribe base (Fan et al., 2009); and state ownership of the media is associated with high levels of bank corruption (Houston et al., 2011). In China, despite more than three decades of economic reforms and fiscal decentralization, both central and local governments still exercise absolute control over the institutional and financial

\footnotetext{
${ }^{2}$ For example, the World Business Environment Survey (WBES) conducted by World Bank.
} 
systems, and corruption acts as the proverbial 'grease' for the bureaucratic 'wheels' of an otherwise unmotivated banking system (Chen et al., 2013). Among the corruption cases we identified in this study (discussed later in Section 3), a close connection has been established through corruption for facilitating firms' access to better investment opportunities. For example, Mr Liu Zhuozhi, the former vice-secretary of Neimenggu province, was arrested on the $15^{\text {th }}$ December 2010. During the period of his incumbency, he accepted bribes of more than 8 million RMB, and in exchange included corrupt firms on the list of qualified bidders, and even facilitated the success of these firms in winning some merger and acquisition projects as well as a set of subsequent local projects. In addition, Mr Huang Yao, the former President of CPPCC in Guizhou province, was arrested on the $22^{\text {nd }}$ February 2010. Before being ousted, he took more than 9 million RMB in bribes in exchange for awarding a set of projects to the bribing firms.

According to a Transparency International survey in 2003, China's Corruption Perception Index ranked in the lower half, with a score of 3.5 (on a scale of 1 to 10, with lower scores indicating greater public perception of corruption); while in 2015 this score (now calculated on a scale of 1 to 100) increased to 37, it was still in the lower half. Moreover, China ranks 83 out of 168 countries on the Corruption Perception Index of Transparency International. La Porta et al. (2004) also report that China is among the worst countries in terms of political freedom and the protection of property rights.

As corruption is expected to be an obstacle to economic growth that cannot be effectively eradicated completely, anti-corruption has continued to be a theme for China; and anticorruption campaigns were put forward in order to restore economic growth and correct the consequences of corruption. Specifically, based on the official records of the Central Commission for Discipline Inspection of the Communist Party of China, over the past three decades to the end of 2011, more than 4.2 million party members were punished by Communist Party law, among them 465 being officials at the level of vice-minister or above. Shortly after the conclusion of the $18^{\text {th }}$ National Congress of the Communist Party of China on the $14^{\text {th }}$ November 2012, when President Xi formally took office, the boldest and most serious anti-corruption campaign was initiated, which has since brought down a large number of Communist Party officials. By the end of 2013, more than 182,000 party officials at various levels had been investigated or arrested, including 43 at the level of vice-minister or above.

\subsection{Hypothesis development}


The Chinese economy is a hybrid of central planning and market-based activities, where the government controls the key resources that are essential for the corporate sector. In this sense, politicians can explicitly and implicitly shape the incentives and decisions of economic entities, by directly controlling the activity of SOEs through government ownership, and indirectly controlling the behaviour of non-SOEs through soft channels (such as regulations, licences, and social and political networks) (Piotroski and Zhang, 2014). Thus, in order to be treated preferentially by the government and gain a competitive advantage, firms have strong incentives to stay close to the government through bribing politicians or forming personal relationships in exchange for contracts and opportunities for private illicit gains (Ngo, 2008; Cai et al., 2011). This suggests that, all else being equal, firms that benefit from political connections may expand their activities increasing investments.

Moreover, existing theory predicts that corporate investment will be hampered due to the lack of sufficient financing, which would be particularly severe for financially constrained firms (Duchin et al., 2010). Political connections are effective in helping firms to overcome the disadvantages of these financing constraints, and are significantly associated with more domestic financing or higher levels of leverage (Leuz and Oberholzer-Gee, 2006; Claessens et al., 2008; Li et al., 2008; Faccio, 2010; Piotroski and Zhang, 2014). Thus, close connections with the government reduce their financial constraints and may facilitate firms to invest more in building their empires.

Nevertheless, to be consistent with the theoretical framework proposed and discussed by $\mathrm{Wu}$ et al. (2012), we argue that the influence of political connections is expected to be different for SOEs and non-SOEs. In particular, SOEs are naturally connected with the government through their government ownership, and are more likely to be favoured by the government in terms of financing and investments (Brandt and $\mathrm{Li}, 2003$ ). In this case, political connections in SOEs do not provide additional benefits in the form of more investment activities. However, non-SOEs have strong incentives to cultivate and maintain close connections with the government, which is helpful in overcoming institutional failure and ideological discrimination against private ownership; and political connections have been documented to be valuable for non-SOEs in areas such as financing and investments ( $\mathrm{Li}$ et al., 2008; Xu et al., 2011; Feng et al., 2015; Lin et al., 2016). If the market expects that rent seeking through political connections leads to benefits for individual firms with respect to investment activities, the competitive advantage for politically connected firms in entering into more investment activities should disappear after the termination of their political connections. Thus, based on our above discussion, we expect that the ousting of connected 
bureaucrats will remove the valuable political capital from non-SOEs, but not necessarily from SOEs. We therefore construct the following hypothesis:

H1: After the ousting of corrupt government officers, politically connected firms experience a significant decline in investment relative to non-politically connected firms in non-SOEs, but not in SOEs.

Although both SOEs and non-SOEs may reduce their respective investment expenditures after the termination of political connections, a natural question that needs to be answered is how firm investment efficiency changes, and how this change varies between SOEs and nonSOEs. In SOEs, if managers have connections with government bureaucrats through bribery or personal relationships, there is a potential for collusion between government officials and SOE managers, because connected SOE managers have more incentives to extract private benefits rather than to maximize shareholder value through either bribery or personal relationships. In this circumstance, SOE managers have stronger incentives for self-dealing behaviour and pursuit of private benefits (such as political promotion, perks and inflated compensation, or taking bribes in the course of obtaining more investment projects). Moreover, in exchange for this self-dealing behaviour, SOE managers also need to satisfy government officials and help in accomplishing social or political objectives that are not necessarily in the best interests of minority shareholders but are preferred by government officials. These causes, then, suggest that excessive investments in SOEs are sub-optimal with low efficiency, and may not provide any additional benefit to shareholders. In addition, soft budget lending resulting from political connections may further exacerbate inefficient investment activities, which in turn encourage these SOEs to invest more for personal objectives, rather than for economic objectives (Zheng and Zhu, 2013). Once the potential collusion or the political connections are terminated, the distorted investment efficiency will be rectified, leading to improved investment efficiency.

On the other hand, unlike the case of SOEs, the dominant objective of non-SOEs is to maximize shareholder value. Thus, we argue that non-SOEs are likely to be involved in maintaining political connections only if those connections bring economic benefits, including profitable investment opportunities. This is particularly important in China, where key investment projects are still regulated and controlled by the government and political connections in non-SOEs are helpful in seeking profitable investment projects and expediting the approval process. The termination of political connections eliminates this advantage, which will reduce investment efficiency in politically connected non-SOEs. Therefore, we construct the following hypothesis: 
H2: After the ousting of corrupt government officers, investment becomes more efficient for politically connected SOEs relative to non-politically connected SOEs, and less efficient for politically connected non-SOEs relative to non-politically connected non-SOEs.

We extend our previous hypotheses by focusing on the recent anti-corruption campaign initiated in China. Since this anti-corruption campaign, more government officials involved in misconduct have been arrested or are under investigation; and this campaign has placed substantial pressure and constraints on the behaviour of incumbent officials. To this extent, the vigorous enforcement of the anti-corruption campaign should reinforce the influence of the termination of political ties, and provides an even stronger experiment that allows us to further identify the causal effect of political power on corporate investment decisions, as this campaign was largely unanticipated by the market. Thus, we formulate the following hypothesis:

H3: The changes in investment and investment efficiency for politically connected firms after the ousting of corrupt government officers are more significant since the recent anticorruption campaign.

\section{Identification, sample and methodology}

\subsection{Identification of the influence of political connections}

The endogeneity issue of political connections is the main concern for empirical study, which is typical for cross-sectional studies. The ideal test would be applying a natural experiment that allows us to avoid the endogeneity issue as well as unobserved confounding factors. Specifically, we collect a sample of corruption scandals involving high-level government officers (provincial level and above) in China, because these corruption scandals are exogenous to the firms and less likely to be anticipated by the market. In particular, we compare the investment and investment efficiency of SOE event firms and non-SOE event firms before and after the arrest of corrupt bureaucrats.

We also consider the effects of regional variation in corruption. China's reform process shows significant characteristics of an uneven distribution of institutional development and corruption levels across different provinces (Chen et al., 2006; Firth et al., 2012). As government officials have a more significant inclination towards bribing firms within the regions with severe corruption, we expect the influence of political connections on corporate investment decisions to be stronger in the regions with a weak institutional environment, including weak legal enforcement.

Finally, we examine the market reaction to these corruption scandals, and change in firm performance before and after the ousting of corrupt bureaucrats, to complement our main 
analysis results. Our arguments predict that corruption creates private benefits, which are obtained by SOE managers, and deteriorates SOE firm performance, while it adds substantial value to non-SOEs. In this sense, investors should react positively towards the ousting of politicians in the case of SOEs, but negatively in the case of non-SOEs.

\subsection{Sample of high-level corruption cases}

To construct a natural experiment, we assemble 104 corruption cases from the beginning of 2003 to the third quarter of 2014. In particular, we focus on high-level government officers for the following reasons. Firstly, these cases usually have larger and more substantial impacts on the corporate sector and the regional economy than general corruption cases have. Secondly, these cases usually attract greater public attention, so that the disclosure of information about these cases is better. Moreover, our identification of high-level corruption cases is also consistent with existing studies in China, which also focus on cases at the provincial level or above (Li and Zhou, 2005; Fan et al., 2008; Piotroski and Zhang, 2014). Thirdly, these cases may mitigate the potential endogeneity concern that corporate investment decisions may cause the enforcement of anti-corruption laws, because these cases are political and less likely to result from their facilitating investment activities to event firms. Data on these corruption cases are hand-collected by searching information published by the Central Commission for Discipline Inspection of the Communist Party of China (CCDI) and supplemented by Baidu (www.baidu.com) and Google (www.google.com) web searches.

Table 1 presents the distribution of the 104 high-level corruption cases, by section and by year, which occurred during our sample period in China. These corruption cases are not concentrated in time up to 2012 , with each calendar year being associated with at least five corruption events. Years 2013 and 2014 are associated with a higher number of corruption events, which corresponds to the anti-corruption policy enforced by the National Congress of the Chinese Communist Party (from the $8^{\text {th }}$ to $14^{\text {th }}$ November 2012), indicating that this new anti-corruption drive is a good natural experiment for examining the effect of political connections on corporate investment decisions. In addition, corruption events are not strictly concentrated in categories. In particular, the central government and affiliated state entities have experienced 23 corruption events, which accounts for $22.12 \%$ of total events over our sample period. Four corruption events come from banks. The most common scenarios of high-level corruption involve officers from provincial governments (77 out of 104).

\section{Table 1.}

Distribution of provincial-level or above corruption cases by section and by year.

This table presents the distribution of corruption cases in China by category and year over the sample period from the beginning of 2003 to the third quarter of 2014. Central refers to the departments of the central 
government; Banks include the People's Bank of China, the big four banks and the three policy banks; Provincial officers include (Vice-) Secretary, (Vice-) Governor, (Vice-) Chairman of both provincial NPC and CPPCC.

\begin{tabular}{lllll}
\hline & Central & Banks & Provincial & Total \\
\hline 2003 & 1 & 1 & 5 & 7 \\
2004 & 2 & 1 & 6 & 9 \\
2005 & 0 & 1 & 7 & 8 \\
2006 & 2 & 0 & 4 & 6 \\
2007 & 0 & 0 & 5 & 5 \\
2008 & 1 & 0 & 4 & 5 \\
2009 & 4 & 1 & 4 & 9 \\
2010 & 1 & 0 & 3 & 4 \\
2011 & 3 & 0 & 2 & 5 \\
2012 & 1 & 0 & 4 & 5 \\
2013 & 5 & 0 & 12 & 17 \\
2014 (by September) & 3 & 0 & 21 & 24 \\
Total & 23 & 4 & 77 & 104 \\
\hline
\end{tabular}

\subsection{Sample of bribing firms and connected firms (event firms)}

To conduct analysis at the firm level, we identify a set of firms that were involved in the corruption cases (bribing firms) or connected with the corrupt bureaucrats through either family members or friendship (connected firms). To do so, we searched through the abovementioned information published by the CCDI, and Baidu and Google. In particular, a bribing firm is identified if any of these information sources indicates that the firm's chairman, CEO, controlling owner or board directors has bribed the corrupt bureaucrats. A connected firm is identified if any of these information sources indicates that the firm's chairman, CEO, controlling owner or board directors are of the same family as, or friends of, the corrupt bureaucrats, or have previous job affiliations with the corrupt bureaucrats. In summary, we identify 112 bribing firms and 87 connected firms over our sample period, including both unlisted firms and firms listed on the Shanghai, Shenzhen or Hong Kong stock exchanges. Due to the limitation of data availability, we exclude 18 firms listed on the Hong Kong stock exchange and 67 unlisted firms, and thus obtain 62 bribing firms and 52 connected firms around the time of the ousting of corrupt officers. For ease of discussion, we term both bribing firms and connected firms as event firms.

\subsection{Sample construction for empirical analysis}

We employ the matching method to construct our empirical sample, which includes both event firms and control firms (non-event firms). For each event firm, a potential match firm is any firm that is not identified as a bribing firm or connected firm, from the same province, the same industry, and the same board (main board or small and medium board), with the same type of ultimate owner (either SOE or non-SOE). From the set of potential matches, we select the one with total asset value closest to that of the event firm at the end of each quarter. 
If no match is found, we release the requirement that both event firms and control firms are from the same industry, and repeat the procedure. If still no match is found, we drop this event firm. As a result of this procedure, our empirical sample is 110 event firms (62 bribing firms and 48 connected firms, and 52 SOEs and 58 non-SOEs) and 110 control firms.

To construct the sample for empirical analysis, we collect quarterly financial data from the third year before to the third year after the corruption event, for both treatment firms and control firms. For firms with less than three years of data either before or after the corruption event, the available quarterly data is taken in a variable. In particular, all quarterly observations used in our empirical analysis are obtained from the China Stock Market and Accounting Research (CSMAR) database, which includes 5082 firm-quarter observations. Consistent with prior studies, we exclude 224 firm-quarter observations from financial industries, 123 firm-quarter observations flagged with ST or *ST, and 213 firm-quarter observations with missing information; and finally obtain 4522 firm-quarter observations for the following empirical analysis. To remove the influence of outliers, we winsorize the top and bottom $1 \%$ of all continuous variables for our empirical analysis.

\subsection{Methodology}

In general, a difference-in-difference (DID) strategy is applied for empirical analysis. To conduct multivariate analysis of the relationship between political connections and corporate investment, we begin with the standard investment regression developed by Fazzari et al. (1988) and used by the following studies: Aivazian et al. (2005), Firth et al. (2008), Chen et al. (2011b), and Xu et al. (2011). Specifically, the model is expressed as follows:

$$
\begin{aligned}
\text { Investment }_{i t}= & \alpha_{0}+\alpha_{1} \text { Corrupt }_{i t}+\alpha_{2} \text { Post }_{i t}+\alpha_{3} \text { Corrupt }_{i t} * \text { Post }_{i t}+\alpha_{4} \text { Leverage }_{i t-1} \\
& +\alpha_{5} Q_{i t-1}+\alpha_{6} \text { Cashflow }_{i t}+\alpha_{7} \text { Size }_{i t}+\alpha_{8} \text { Sale }_{i t-1}+\alpha_{9} \text { Tangibility } \\
& + \text { Industry } \text { Quarter } \varepsilon_{i t}
\end{aligned}
$$

where Investment is firms' investment expenditures. We follow Chen et al. (2011b) and Xu et al. (2011) to measure investment expenditures as the ratio of capital expenditure (cash payments for fixed assets, intangible assets, and other long-term assets less cash receipts from selling these assets) to total assets. An alternative measure, the ratio of net capital expenditure (capital expenditure minus depreciation) to total assets (Firth et al., 2008), is considered for the robustness tests. Corrupt is a dummy variable equal to 1 for bribing firms and connected firms, and 0 for other firms. Post is a dummy variable equal to 1 for the period after the corrupt bureaucrats were arrested, and 0 for the period before. The interaction term Corrupt*Post is added to capture the post-event changes in the investment activities of event firms relative to control firms. We test $\mathrm{H} 1$ by estimating equation (1) for both SOE and non- 
SOE subsamples, and expect the coefficients of Corrupt*Post to be significantly negative in non-SOEs. Leverage is the ratio of firm total debt to total assets. $Q$ is Tobin's Q, calculated as the sum of market value of tradable shares, book value of non-tradable shares and liabilities, divided by the sum of book value of equity and liabilities. We calculate the book value of non-tradable shares because of their illiquidity, and because they are normally traded at a price close to the book value of equity (Chen et al., 2011). If a firm has no non-tradable shares, then the book value of non-tradable shares is removed from the calculation of Tobin's Q. Cashflow is the ratio of firms' operating cash flows to total assets. Size is the log of firms' total assets. Sale is the ratio of net sales to total assets. Tangibility is the ratio of tangible assets to firms' total assets. Industry and quarterly fixed effects are also included.

To examine corporate investment efficiency, we follow the method used by Chen et al. (2011b) and use the sensitivity of investment expenditure to investment opportunities to measure investment efficiency, and efficient investment is reflected by a close relationship between investment expenditure and investment opportunities. In particular, the equation to be estimated is expressed as follows:

$$
\begin{aligned}
\text { Investment }_{i t}= & \alpha_{0}+\alpha_{1} \text { Corrupt }_{i t}+\alpha_{2} \text { Post }_{i t}+\alpha_{3} \text { Corrupt }_{i t}^{*} Q_{i t-1}+\alpha_{4} \text { Post }_{i t}^{*} Q_{i t-1} \\
& +\alpha_{5} \text { Corrupt }_{i t} \text { Post }_{i t}+\alpha_{6} \text { Corrupt }_{i t}^{*} \text { Post }_{i t}^{*} Q_{i t-1} \\
& ++\alpha_{7} Q_{i t-1}+\alpha_{8} \text { Leverage }_{i t-1}+\alpha_{9} \text { Cashflow }_{i t}+\alpha_{10} \text { Size }_{i t} \\
& +\alpha_{11} \text { Sale }_{i t-1}+\alpha_{12} \text { Tangibility }_{i t}+\text { Industry }+ \text { Quarter }+\varepsilon_{i t}
\end{aligned}
$$

where $Q$ is measured by Tobin's $\mathrm{Q}$, which is used as the proxy for investment opportunities. We also include quarter and industry dummy variables to control for the time and industry fixed effects. All the other variables are defined as in equation (1). We test $\mathrm{H} 2$ by estimating equation (2) for both SOE and non-SOE subsamples, and expect the coefficients of Corrupt $^{*} \operatorname{Post}^{*} Q$ to be positive in SOEs and negative in non-SOEs. Table 2 summarizes the definitions of all variables used in this study for both univariate and multivariate analysis.

When estimating the investment-Q relationship in equation (2) to assess investment efficiency, we notice an important issue of the measurement error in Tobin's Q, which has been discussed extensively in existing studies ${ }^{3}$. In this case, the ordinary least square (OLS) estimation method might lead to biased and inconsistent coefficients, and the results become unreliable. Therefore, to provide unbiased and consistent estimations of coefficients, we use the instrumental variable (IV) approach for estimation (Robert and Whited, 2012). In our estimation, we treat Tobin's Q and its interaction terms with other variables as mismeasured,

\footnotetext{
${ }^{3}$ Please see, for example, Erickson and Whited (2000) and Robert and Whited (2012) for detailed discussions of the measurement error in Tobin's Q, and the proposed remedies to deal with the measurement error.
} 
and use the lagged mismeasured variables as the instruments, following Erickson and Whited (2012) and Robert and Whited (2012). However, we admit that the IV approach does not necessarily dominate other methods in addressing measurement error, so we use other methods to check the robustness of our main results in a later section.

Table 2

Variables and definitions

This table lists the symbols and corresponding definitions of variables.

\begin{tabular}{ll}
\hline Variable & Definitions \\
\hline Investment (I) & Capital expenditure / Total assets in the current quarter \\
Q & Tobin's Q, measured as the sum of market value of tradable shares, book value of \\
non-tradable shares and liabilities, divided by the sum of book value of equity and \\
liabilities, in the current quarter. If a firm has no non-tradable shares, then the \\
book value of non-tradable shares is removed from this calculation. \\
A dummy variable equal to 1 for event firms and 0 for control firms \\
Corrupt & A dummy variable equal to 1 for post-event period and 0 otherwise \\
Post & Total debt/Total assets in the current quarter \\
Leverage & (Net income + depreciation) / Total assets in the current quarter \\
Cashflow & Natural log of total assets in the current quarter \\
Size & Sales / Total assets in the current quarter \\
Sale & Tangible assets / Total assets in the current quarter \\
Tangibility & Net income / Total assets \\
ROA & A dummy variable equal to 1 for observations falling after the $18^{\text {th }}$ Congress \\
Campaign & conference and 0 otherwise \\
Perk & Total perks / Sales \\
Lnpay & Natural log of the average compensation of top three executives \\
\hline
\end{tabular}

\section{Empirical results}

\subsection{Summary statistics and univariate tests}

Table 3 presents the summary statistics for investment expenditures, Tobin's Q, as well as other variables used in our study, for the full sample, event firm sample, and control firm sample. Before proceeding, the construction of some variables using the data from income statements and cash flow statements needs to be noted (these variables include investment expenditures, cash flow and sales level, and return on assets). The quarterly data obtained from the income statements and cash flow statements of the CSMAR database actually records the cash transactions from the beginning of the current year. Thus, we calculate the difference between two consecutive quarterly observations within the same year, to figure out the cash transactions for a particular quarter. For example, the observations of investment by the end of 2013Q2 and 2013Q3 record the investment activities for the first two and three quarters in 2013, respectively; so the difference (2013Q3-2013Q2) is actually the investment activities for the third quarter of 2013. In our sample, 53\% of firms are non-SOEs, and others are SOEs. As can be seen from Panel A of Table 3 for the full sample, the average corporate investment expenditure level is $2.41 \%$, and the average quarterly Tobin's Q is 1.84 . We also present the average leverage ratio as $56.75 \%$, and the mean (median) free cash flow ratio and 
sales ratio are $1.89 \%(1.69 \%)$ and $15.16 \%(12.08 \%)$, respectively. In Panels B and C, we summarize the statistics for both event firm sample and control firm sample, respectively. It is clear that the firm sizes are quite similar for both samples, which validates our matching procedure. We also observe some differences in other variables between both samples, which will be included as control variables in our regression analysis.

Table 3

Summary statistics

This table presents summary statistics of all variables used in our study. Definitions of these variables are the same as in Table 2.

\begin{tabular}{|c|c|c|c|c|}
\hline & Mean & Median & $25 \%$ quartile & $75 \%$ quartile \\
\hline \multicolumn{5}{|c|}{ Panel A: Full sample } \\
\hline Investment (I) & $2.41 \%$ & $0.86 \%$ & $0.22 \%$ & $2.50 \%$ \\
\hline Q & 1.84 & 1.36 & 1.08 & 2.00 \\
\hline Leverage & $56.75 \%$ & $52.18 \%$ & $34.58 \%$ & $70.36 \%$ \\
\hline Cashflow & $1.89 \%$ & $1.69 \%$ & $-7.60 \%$ & $11.90 \%$ \\
\hline Size & 21.68 & 21.52 & 20.49 & 22.51 \\
\hline Sale & $15.16 \%$ & $12.08 \%$ & $5.99 \%$ & $19.75 \%$ \\
\hline Tangibility & $23.22 \%$ & $18.72 \%$ & $7.20 \%$ & $35.13 \%$ \\
\hline ROA & $0.58 \%$ & $0.47 \%$ & $0.01 \%$ & $0.96 \%$ \\
\hline Perks & 0.011 & 0.005 & 0.003 & 0.009 \\
\hline Lnpay & 12.64 & 12.70 & 12.13 & 13.20 \\
\hline \multicolumn{5}{|c|}{ Panel B: Event firm sample } \\
\hline Investment (I) & $2.51 \%$ & $0.94 \%$ & $0.25 \%$ & $2.56 \%$ \\
\hline Q & 1.79 & 1.35 & 1.08 & 1.98 \\
\hline Leverage & $57.37 \%$ & $52.53 \%$ & $35.37 \%$ & $71.45 \%$ \\
\hline Cashflow & $2.27 \%$ & $1.72 \%$ & $-6.85 \%$ & $12.40 \%$ \\
\hline Size & 21.70 & 21.50 & 20.58 & 22.59 \\
\hline Sale & $14.64 \%$ & $11.92 \%$ & $5.65 \%$ & $19.67 \%$ \\
\hline Tangibility & $21.75 \%$ & $17.63 \%$ & $7.16 \%$ & $32.12 \%$ \\
\hline ROA & $0.39 \%$ & $0.28 \%$ & $-0.32 \%$ & $0.47 \%$ \\
\hline Perks & 0.012 & 0.006 & 0.004 & 0.010 \\
\hline Lnpay & 12.53 & 12.63 & 12.09 & 13.10 \\
\hline \multicolumn{5}{|c|}{ Panel C: Non-event firm sample } \\
\hline Investment (I) & $2.32 \%$ & $0.78 \%$ & $0.21 \%$ & $2.42 \%$ \\
\hline Q & 1.90 & 1.38 & 1.09 & 2.04 \\
\hline Leverage & $56.13 \%$ & $51.22 \%$ & $33.16 \%$ & $69.32 \%$ \\
\hline Cashflow & $1.51 \%$ & $1.68 \%$ & $-8.62 \%$ & $11.01 \%$ \\
\hline Size & 21.66 & 21.55 & 20.39 & 22.43 \\
\hline Sale & $15.68 \%$ & $12.27 \%$ & $6.08 \%$ & $20.30 \%$ \\
\hline Tangibility & $24.69 \%$ & $20.57 \%$ & $7.26 \%$ & $37.45 \%$ \\
\hline ROA & $0.77 \%$ & $0.68 \%$ & $0.02 \%$ & $1.23 \%$ \\
\hline Perks & 0.010 & 0.004 & 0.002 & 0.008 \\
\hline Lnpay & 12.75 & 12.78 & 12.15 & 13.31 \\
\hline
\end{tabular}

To provide some empirical evidence to support our hypotheses, we conduct univariate tests by comparing the average of corporate investment expenditures between event firms and non-event firms for the full sample, SOE sample and non-SOE sample, with the results shown in Table 4. In particular, for the event firms in Panel A, the mean values of average investment are $3.05 \%$ and $1.07 \%$ before and after the ousting of corrupt politicians, respectively, and the difference is $1.98 \%$, which is significant at the $1 \%$ level (t-value is 3.27 ). For the non-event firms, the mean values of investment are $2.74 \%$ and $1.06 \%$, respectively, 
and the difference is $1.68 \%$, significant at the $10 \%$ level (t-value is 1.80$)$. In the right bottom cell, we report the difference between the changes in investment expenditures for event firms and non-event firms. We observe that the difference is $0.30 \%$, which is significant at the $5 \%$ level (t-value is 2.13). These results suggest that the investment expenditures have been reduced significantly after the arrest of corrupt bureaucrats, which is more pronounced for event firms. In Panels B and C, we repeat our comparison to check the changes in investment expenditures for both SOE and non-SOE samples. Consistent with the evidence for the full sample, the changes in average investment expenditures are higher for event firms for both SOE and non-SOE samples. However, the difference of reduction in the investment expenditures after the arrest of corrupt bureaucrats between event firms and non-event firms is significant in non-SOEs at the $1 \%$ level, but not in SOEs. Overall, the results from Table 4 lend support to our hypothesis that, after the ousting of corrupt bureaucrats, investment expenditures decline more for event firms than for non-event firms, which is significant for non-SOE event firms but not for SOE event firms. These results indicate that political connections are effective in facilitating corporate investment, and the termination of connections with the government will adversely affect corporate investment.

\section{Table 4}

Univariate tests

This table reports the mean values of corporate investment expenditures for the sample of event firms and non-event firms before and after the corruption event. Event firms include those firms identified as having bribed corrupt government officers and those firms identified as having connections with corrupt government officers. $*, * *$ and $* * *$ indicate significance at the $10 \%, 5 \%$ and $1 \%$ levels, respectively.

\begin{tabular}{llll}
\hline & Before the corruption event & After the corruption event & Difference test (t-value) \\
\hline Panel A: Full sample & & & \\
\hline $\begin{array}{l}\text { Event firms } \\
\text { Non-event firms }\end{array}$ & $3.05 \%$ & $1.07 \%$ & $1.98 \% * *(3.27)$ \\
$\begin{array}{l}\text { Difference-in- } \\
\text { difference test (t-value) }\end{array}$ & $2.74 \%$ & $1.06 \%$ & $0.30 \% * *(2.13)$ \\
\hline Panel B: SOE sample & & \\
\hline $\begin{array}{l}\text { Event firms } \\
\text { Non-event firms }\end{array}$ & $2.98 \%$ & $1.09 \%$ & $1.89 \% * *(2.51)$ \\
$\begin{array}{l}\text { Difference-in- } \\
\text { difference test (t-value) }\end{array}$ & $1.22 \%$ & $1.71 \% * *(1.97)$ \\
\hline Panel C: Non-SOE sample & & $0.18 \%(0.93)$ \\
\hline $\begin{array}{l}\text { Event firms } \\
\text { Non-event firms }\end{array}$ & $3.41 \%$ & & \\
$\begin{array}{l}\text { Difference-in- } \\
\text { difference test (t-value) }\end{array}$ & $2.49 \%$ & $0.89 \%$ & $2.52 \% * * *(3.70)$ \\
\hline
\end{tabular}

\subsection{Political connections, ultimate owner type and investment expenditures}

In this section, we perform regression analysis to examine whether corporate investment decisions change after the corruption event, by estimating equation (1), and report the results in Table 5. 
Column 1 presents the results for the full sample, and columns 2 and 3 present the results for both SOE and non-SOE samples. Across three specifications, we observe that the estimated coefficients on Corrupt are all positive while insignificant, indicating that the average investment expenditures are higher for event firms than non-event firms, while the difference is not significant. We also find that the estimated coefficients on Post are all negative and statistically significant at the $1 \%$ levels. This result suggests that the average investment expenditures decline significantly after the termination of political connections, which is significant for both SOEs and non-SOEs. We are particularly interested in the coefficients of the interaction term Corrupt*Post. In the first column for the full sample, the estimated coefficient is -0.04 , significant at the $5 \%$ level ( $\mathrm{t}$-value is -2.21 ), indicating that the average investment expenditures decline significantly for event firms after the termination of the political connections, compared with non-event firms. When we turn to subsample estimations, we observe that the significant coefficient holds for non-SOEs, while it is insignificant for SOEs. We also conduct the Chow test to formally examine the significance of the difference between the coefficients of the Corrupt*Post for SOEs and non-SOEs. The Chow test result shows that the influence of political connection terminations is stronger for non-SOEs than for SOEs $(\mathrm{F}=4.56, \mathrm{p}<0.05)$.

The results in Table 5 are consistent with our hypothesis H1, that non-SOE event firms experience a more significant decline of investment expenditures compared with non-SOE non-event firms, while the decline in investment expenditures for SOE event firms is insignificantly different from that for SOE non-event firms. This also confirms our argument that SOEs are treated preferentially by the government in terms of financing and investment, while the success of non-SOEs relies largely on their connections with the government, so that the decline in investment is not expected to be significant for SOEs relative to non-SOEs after the termination of political connections.

\section{Table 5}

The effect of political connections on corporate investment expenditures

This table presents the regression results of the effect of political connections on corporate investment expenditures. Quarterly observations for the event firms and control firms from three years before to three years after the event of corruption are applied in the regressions. The dependent variable is corporate investment, defined as the ratio of capital expenditures to total assets. Corrupt is a dummy variable, equal to 1 for firms bribing government officers or connected with the corrupt government officers, and 0 otherwise. Post is a dummy variable, equal to 1 for observations of the post-event period, and 0 otherwise. All the other variables are defined as in Table 2. T-statistics are in parentheses, computed using the robust standard error clustered by the firm. $* * *$ and $* * *$ indicate significance at the $10 \%, 5 \%$ and $1 \%$ levels, respectively.

Dependent variable is corporate investment expenditures

\begin{tabular}{llll}
\hline & Full sample & SOE sample & Non-SOE sample \\
\hline Corrupt & $0.02(1.56)$ & $0.01(0.65)$ & $0.03(1.42)$ \\
Post & $-0.06 * *(-5.50)$ & $-0.03 * * *(-4.16)$ & $-0.08 * * *(-4.45)$ \\
Corrupt*Post & $-0.04 * *(-2.21)$ & $-0.01(-0.62)$ & $-0.07 * *(-2.30)$
\end{tabular}




\begin{tabular}{llll} 
Leverage & $-0.05 * * *(-5.70)$ & $-0.10^{* * *(-6.94)}$ & $-0.05 * * *(-4.79)$ \\
Q & $0.07 * *(2.06)$ & $0.08^{*}(1.80)$ & $0.08(1.43)$ \\
Cashflow & $0.37 * * *(4.10)$ & $0.48^{* * *(6.22)}$ & $0.31 * *(2.49)$ \\
Size & $0.04 *(1.77)$ & $0.10^{* * *(4.64)}$ & $0.04(0.81)$ \\
Sale & $0.03(1.40)$ & $0.07 * * *(3.07)$ & $0.01(0.23)$ \\
Tangibility & $0.10^{* * *(11.82)}$ & $0.04 * * *(3.62)$ & $0.11 * * *(10.48)$ \\
Constant & $0.08(1.56)$ & $-0.04(-0.72)$ & $0.29 * *(2.25)$ \\
Quarter fixed effects & Included & Included & Included \\
Industry fixed effects & Included & Included & Included \\
Chow test & & $4.56^{* *}$ & 0.43 \\
Adjusted R square & 0.37 & 0.23 & 2394 \\
Observations & 4522 & 2128 & \\
\hline
\end{tabular}

Among the control variables, we observe signs of all control variables consistent with previous studies (Firth et al., 2008, 2012; Chen et al., 2011b). In particular, leverage is negatively and significantly related to corporate investment, which is consistent with the debt overhang/debt pre-commitment problems (Myers, 1977; Stulz, 1990). The positive coefficient on Tobin's Q suggests that corporate investment depends largely on firm investment opportunities. We also observe that firms' free cash flow and gross profits are both positively related to investment, indicating that more availability of cash encourages firms' investment activities. Furthermore, both firm total assets and tangible assets are significantly associated with investment expenditures, indicating that larger-sized firms invest more.

\subsection{Political connections, ultimate owner type and investment efficiency}

In this section, we examine the change in investment efficiency, to further complete our investigation. In particular, we estimate equation (2) and report the results in Table 6.

Our estimations for the full sample are in column 1, and for both SOE and non-SOE samples in columns 2 and 3, respectively. The estimated coefficients on Corrupt, Post and Corrupt*Post are generally similar to those reported in Table 5. Across three specifications, we are more concerned about the interaction terms of $Q$ with Corrupt and/or Post. For the full sample in column 1 , we observe that the estimated coefficient on $\operatorname{Corrupt}^{*} Q$ is positive, indicating that, on average, event firms usually have higher investment efficiency relative to non-event firms, although the difference is insignificant. Both $\operatorname{Post}^{*} Q$ and $\operatorname{Corrupt}^{*} \operatorname{Post}^{*} Q$ show insignificant coefficients.

More interestingly, SOEs and non-SOEs show substantial differences with respect to investment efficiencies. In particular, in column 2 for SOEs, we find that estimated coefficients of $\operatorname{Post}^{*} Q$ and $\operatorname{Corrupt}^{*} \operatorname{Post}^{*} Q$ are both positive and statistically significant at $10 \%$ and $5 \%$ levels, respectively (t-values are 1.68 and 2.39 , respectively), indicating that investment efficiency has improved after the termination of political connections, which is 
more pronounced for event SOEs relative to non-event SOEs. In column 3 for non-SOEs, we observe that the coefficients of both $\operatorname{Post}^{*} Q$ and $\operatorname{Corrupt}^{*} \operatorname{Post}^{*} Q$ are negative and statistically significant ( $\mathrm{t}$-values are -1.82 and -3.05 , respectively), indicating that, after the termination of political connections, investment efficiency has declined for non-SOEs, which is more pronounced for event non-SOEs relative to non-event non-SOEs. Due to the potential issue of measurement error in Tobin's Q, we apply the IV approach for estimation, and use the lagged mismeasured variables as the instruments, following Erickson and Whited (2012). In all specifications, we also conduct the over-identification tests to examine whether the instrument variables are valid. The unreported p-values of the over-identification tests are all larger than 0.1, indicating that the instruments we used are valid. As with Table 5, we also conduct the Chow test, and the results $(\mathrm{F}=6.49, \mathrm{p}<0.01)$ confirm a significant difference in the influence of the termination of political connections on investment efficiency between SOEs and non-SOEs.

These results support our hypothesis H2, that after the ousting of corrupt officers, investment efficiency improves for event SOEs compared with non-event SOEs, while it declines for event non-SOEs compared with non-event non-SOEs. These results suggest that rent seeking with bribery is detrimental in SOEs (sanding the wheel), so that investment efficiency recovers after the corruption events, while it is beneficial for non-SOEs (greasing the wheel). Our results also corroborate the findings of existing studies (Chen et al., 2011b; Zheng and Zhu, 2013).

\section{Table 6}

The effect of political connections on corporate investment efficiency

This table presents the regression results of the effect of political connections on corporate investment efficiency. Quarterly observations for the event firms and control firms from three years before to three years after the event of corruption are applied in the regressions. The dependent variable is corporate investment expenditure. Corrupt is a dummy variable, equal to 1 for firms bribing government officers or connected with the corrupt government officers, and 0 otherwise. Post is a dummy variable, equal to 1 for observations of the post-event period, and 0 otherwise. All the other variables are defined as in Table 2. T-statistics are in parentheses, computed using the robust standard error clustered by the firm. *, **and *** indicate significance at the $10 \%, 5 \%$ and $1 \%$ levels, respectively.

\begin{tabular}{llll}
\hline \multicolumn{1}{l}{ Dependent variable is the investment expenditure } & & \\
\hline Corrupt & Full sample & SOE sample & Non-SOE sample \\
Post & $0.07(0.70)$ & $0.02(0.19)$ & $0.17 *(1.91)$ \\
Corrupt*Post & $-0.16^{* *(-2.10)}$ & $-0.01 * *(-2.02)$ & $-0.34 * * *(-3.05)$ \\
Corrupt*Q & $-0.04(-0.36)$ & $-0.03(-1.14)$ & $-0.17 * *(-2.24)$ \\
Post*Q & $0.02(0.61)$ & $-0.01(-0.28)$ & $0.04(0.93)$ \\
Corrupt*Post*Q & $0.04(1.45)$ & $0.03 *(1.68)$ & $-0.10 *(-1.82)$ \\
Q & $0.03(0.06)$ & $0.05 * *(2.39)$ & $-0.05 * * *(-3.05)$ \\
Leverage & $0.05 *(2.19)$ & $0.02 * * *(2.58)$ & $0.07 *(1.89)$ \\
Cashflow & $-0.11 * *(-2.09)$ & $-0.19 * * *(-2.57)$ & $-0.12 * *(-1.98)$ \\
Size & $0.74 *(1.91)$ & $1.21 * * *(5.59)$ & $0.55(1.05)$ \\
Sale & $0.02(1.08)$ & $0.02 *(1.75)$ & $0.01(0.42)$ \\
Tangibility & $0.24 * *(3.03)$ & $0.25 * * *(4.70)$ & $0.24 * *(2.05)$ \\
\hline
\end{tabular}




\begin{tabular}{llll}
\hline Constant & $0.10(0.37)$ & $-0.15(-0.57)$ & $0.23(0.36)$ \\
Quarter fixed effects & Included & Included & Included \\
Industry fixed effects & Included & Included & \\
Chow test & & $6.49^{* * *}$ & \\
Adjusted R square & 0.48 & 0.25 & 0.53 \\
Over identification test & 0.48 & 0.50 & 0.33 \\
Observations & 4522 & 2128 & 2394 \\
\hline
\end{tabular}

\subsection{Bribing firms vs. connected firms}

Our foregoing results are derived based on a sample that includes both bribing firms and connected firms, and their matching firms. However, bribing firms and connected firms are connected with governments in different ways, so that their respective political connections may demonstrate different effects on firm investment decisions. Specifically, compared with connected firms, bribing firms are more likely to devote firm resources to the building of political connections in order to seek rents from government. Then, according to our theoretical argument in developing hypotheses, managers of SOE bribing firms can extract more private benefits due to a lack of monitoring, and these firms are less likely to invest for the creation of economic value and will thus have less efficient investment. However, in nonSOEs, bribery brings more favourable treatment and investment opportunities to the firms, and this outweighs the cost of the bribery, so that non-SOEs invest more efficiently to create value-adding for the firms, as their objective is value maximization. Thus, SOE (non-SOE) bribing firms may experience a larger improvement (reduction) in their investment efficiency after the termination of political connections, relative to SOE (non-SOE) connected firms. Thus, it is necessary and valuable to distinguish bribing firms from connected firms, and to investigate the differential effects of political connections.

To address this issue and test our expectations, we re-estimate both equations (1) and (2) using the event firm sample. In particular, we replace Corrupt with Bribe, which is a dummy variable and equals 1 for bribing firms, and 0 for connected firms. We also conduct the same estimations for both the SOE and non-SOE samples, and the results are reported in Table 7. In Panel A, the coefficients of Bribe*Post are our main concern; and they are significantly negative for the SOE sample and insignificant for the non-SOE sample. These results indicate that in SOEs, compared with connected firms, bribing firms experience a larger decline in investment expenditures after the termination of political connections, but this difference is insignificant in non-SOEs. In Panel B, our concern is the coefficients of Bribe*Post ${ }^{*} Q$. We find that this coefficient is significantly positive for the SOE sample and negative for nonSOE sample. These results suggest that, compared with connected firms, bribing firms improve their investment efficiency more in SOEs, while they deteriorate more in non-SOEs. 
Overall, this test confirms our expectation that different types of political connections demonstrate differential effects on firm investment decisions ${ }^{4}$.

Table 7.

The effect of political connections on investment expenditures and efficiency for the event firm sample

This table presents the regression results on the effect of political connections on corporate investment decisions for the event firm sample. Quarterly observations for the event firms from three years before to three years after the event of corruption are applied in the regressions. The dependent variables are corporate investment expenditure in Panels A and B. Bribe is a dummy variable, equal to 1 for bribing firms, and 0 for connected firms. All the other variables are defined as in Table 2. T-statistics are in parentheses, computed using the robust standard error clustered by the firm. $*$ and $* *$ indicate significance at the $10 \%$ and $5 \%$ levels, respectively.

\begin{tabular}{llll}
\hline \multicolumn{1}{c}{ Full sample } & \multicolumn{1}{l}{ SOEs } & \multicolumn{1}{l}{ Non-SOEs } \\
\hline \multicolumn{2}{l}{ Panel A: Investment expenditure regression } & & \\
\hline Bribe & $0.01(0.86)$ & $0.03^{* *}(2.34)$ & $-0.02(-1.19)$ \\
Post & $-0.01 * *(-1.96)$ & $-0.01 * *(-2.49)$ & $-0.01 *(-1.86)$ \\
Bribe*Post & $0.01(0.26)$ & $-0.02 *(-1.67)$ & $0.02(1.22)$
\end{tabular}

Control variables in each regression include firm size, leverage, tangible assets, free cash flow, and industry and quarter fixed effects

$\begin{array}{llll}\text { Adjusted R square } & 0.36 & 0.22 & 0.39\end{array}$

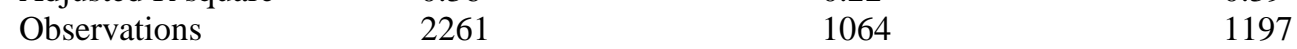

\begin{tabular}{llll}
\hline \multicolumn{2}{l}{ Panel B: Investment efficiency regression } & & \\
\hline Bribe & $0.11(0.91)$ & $0.03(0.55)$ & $0.46(0.45)$ \\
Bribe*Q & $0.03(0.61)$ & $-0.09(-1.28)$ & $0.13^{* *}(2.08)$ \\
Bribe*Post*Q & $0.07 *(1.79)$ & $0.09 *(1.80)$ & $-0.02 * *(-2.30)$
\end{tabular}

Control variables in each regression include firm size, leverage, tangible assets, free cash flow, and industry and quarter fixed effects. Other interaction terms between each pair of our interest variables are also included in each regression

Chow test $6.55^{* *}$

$\begin{array}{llll}\text { Adjusted R square } & 0.41 & 0.32 & 0.44\end{array}$

Over identification test $\quad 0.68 \quad 0.70 \quad 0.55$

$\begin{array}{llll}\text { Observations } & 2261 & 1064 & 1197\end{array}$

\subsection{Alternative explanation and robustness tests}

We interpret our findings by referring to the termination of political connections. Nevertheless, there is an alternative explanation concerning firms' reputation. If the ousting of the corrupt officials was publicly released, it is a natural expectation that the reputation of event firms will be damaged, which in turn will affect their investment decisions. To rule out this alternative explanation, we compare the investment decisions in the third year before the public release of corruption cases. Empirically, we repeat previous regressions by limiting our sample to observations in that year, and report the results in Table 8. This cross-sectional comparison allows us to examine whether close connections with governments may boost firms' investment, and influence investment efficiency, differently in SOEs and non-SOEs. As shown in Panel A, we find that the estimated coefficients of Corrupt are all positive and significant for non-SOEs. The results from Panel B show that estimated coefficients of $\operatorname{Corrupt}^{*} Q$ are positive for non-SOEs and negative for SOEs. Overall, these results suggest

\footnotetext{
${ }^{4} \mathrm{We}$ thank the reviewer for raising this issue and for the tests.
} 
that well before the influence of the corruption scandals was felt, the event firms had more investment expenditures than non-event firms, and that this difference is more significant in non-SOEs. These results also show that compared with their non-event counterparts, event SOEs exhibit less efficient investment, while event non-SOEs have more efficient investment. Hence, the change in investment decisions following the corruption event is unlikely to be driven by the public concern about reputation.

Table 8.

The effect of political connections on investment expenditures and efficiency before the ousting of corrupt official (observations of the third year before the corruption cases)

This table presents the regression results of the effect of political connections on corporate investment decisions before the ousting of corrupt officials. Observations for the event firms and control firms in the third year before the corruption events are applied in the regressions. The dependent variables are corporate investment expenditure in Panels A and B. Corrupt is a dummy variable, equal to 1 for firms bribing government officers or connected with the corrupt government officers, and 0 otherwise. All the other variables are defined as in Table 2. T-statistics are in parentheses, computed using the robust standard error clustered by the firm. ${ }^{*}$ and $* *$ indicate significance at the $10 \%$ and $5 \%$ levels, respectively.

\begin{tabular}{|c|c|c|c|}
\hline & Full sample & SOEs & Non-SOEs \\
\hline \multicolumn{4}{|c|}{ Panel A: Investment expenditure regression } \\
\hline Corrupt & $0.02 *(1.71)$ & $0.04(0.90)$ & $0.01 *(1.74)$ \\
\hline \multicolumn{4}{|c|}{$\begin{array}{l}\text { Control variables in each regression include firm size, leverage, tangible assets, sales, free cash flow, Tobin's Q, } \\
\text { and industry fixed effects }\end{array}$} \\
\hline Chow test & & $2.87 *$ & \\
\hline Adjusted R square & 0.29 & 0.19 & 0.30 \\
\hline Observations & 671 & 329 & 342 \\
\hline \multicolumn{4}{|c|}{ Panel B: Investment efficiency regression } \\
\hline Corrupt & $0.05(0.32)$ & $0.04(0.30)$ & $0.07(0.22)$ \\
\hline Corrupt*Q & $-0.03(-0.61)$ & $-0.05 *(-1.76)$ & $0.03 * *(2.40)$ \\
\hline Q & $0.08 * *(1.96)$ & $0.04 *(1.90)$ & $0.13 * *(1.98)$ \\
\hline \multicolumn{4}{|c|}{$\begin{array}{l}\text { Control variables in each regression include firm size, leverage, tangible assets, sales, free cash flow and } \\
\text { industry fixed effects }\end{array}$} \\
\hline Chow test & & $4.33 * *$ & \\
\hline Adjusted R square & 0.57 & 0.17 & 0.62 \\
\hline Over identification test & 0.22 & 0.30 & 0.27 \\
\hline Observations & 671 & 329 & 342 \\
\hline
\end{tabular}

In the prior analysis, we measure political connections through bribing activities and personal relationships. However, a parallel strand of literature argues that firms' location also forms a powerful basis for political connections or proximity to political power (Faccio and Parsley, 2009; Kim et al. 2012). In view of this, our results may be driven by this alternative explanation, as some event firms in our sample are located in the same jurisdiction as corrupt politicians, and these firms are already favoured by politicians in spite of bribing activities or personal relationships. To rule out this alternative explanation, we repeat the previous analysis by partitioning our full sample into two subsamples based on whether firms are located in the same jurisdiction as corrupt politicians. For the sake of brevity, we do not report the results in the paper. The unreported results show that our main results still hold in both subsamples, which validates our hypothesis. 
In addition, it could also be argued that, if both SOEs and non-SOEs are connected to the same corrupt bureaucrat, customers may switch from non-SOEs to SOEs because they believe that non-SOEs will deteriorate their productivity due to the loss of political connections. If this is the case, these connected SOEs could be better off, due to the shock of positive demand, and improve their investment efficiency ${ }^{5}$. To rule out this possibility, we repeat our previous regression analysis by including the corrupt bureaucrats that are connected to only one non-SOE or SOE. To save space, we do not report the results in the paper, but they are available on request. The unreported results are similar to those reported in both Tables 5 and 6, confirming that the differential trends between SOEs and non-SOEs still hold for the alternative samples, and that changes in firms' investment decisions are mainly influenced by the termination of political connections.

We also conduct a series of other robustness tests. Firstly, in previous analyses, we constructed the control sample based on firm total assets by using the matching method. Now, we conduct the propensity score matching (PSM) method to reconstruct our control sample. In particular, the candidate firms for the matching process are from the same industry and the same year, with the same type of ultimate owner. Then, we select the optimal match based on the closest propensity score of being politically connected. To calculate the propensity score, we include a set of firm characteristics that can capture the probability of being event firms, namely firm size, leverage, the largest shareholder ownership and state ownership, following existing studies (Faccio et al., 2006; Boubakri et al., 2012) ${ }^{6}$. Secondly, instead of conducting regression estimations for the SOE and non-SOEs samples separately, we conduct regression estimation using the full sample and include an SOE dummy and its interaction terms with our key variables. Specifically, the SOE dummy equals 1 for SOEs, and 0 for non-SOEs. The results of the above tests are reported in Table 9. To save space, we only report the key variables from the investment expenditure equation, while full results are available on request. These results are similar to those reported in previous tables, and are consistent with our main hypotheses that the termination of political connections affect firms' investment decisions.

\section{Table 9}

The effect of political connections on corporate investment expenditures (robustness tests)

This table presents the regression results of the effect of political connections on corporate investment expenditures. The dependent variable is corporate investment expenditure. Corrupt is a dummy variable, equal

\footnotetext{
${ }^{5}$ We thank the reviewer for pointing out this issue.

${ }^{6}$ Following this PSM, we are able to collect 4720 firm-quarter observations. This sample size is slightly different from the 4522 based on the total assets matching. This is because we identify control firms with the treatment firms at the time of the quarter in which the corruption event occurs. Thus, using different matching methods, we construct a control sample including different firms, and these different sets of control firms may have different data available from three years before to three years after the corruption events.
} 
to 1 for firms bribing government officers or connected with corrupt government officers, and 0 otherwise. Post is a dummy variable, equal to 1 for observations of post-event period, and 0 otherwise. All the other variables are defined as in Table 2. T-statistics are in parentheses, computed using the robust standard error clustered by the firm. * and $* * *$ indicate significance at the $10 \%$ and $1 \%$ levels, respectively.

Dependent variable is corporate investment expenditures

\begin{tabular}{lcc} 
& PSM matching sample & Full sample with SOE dummy \\
\hline Corrupt & $0.04(0.53)$ & $0.01 *(1.81)$ \\
Post & $-0.08^{*}(-1.92)$ & $-0.02 * * *(-4.33)$ \\
Corrupt*Post & $-0.05^{* * *(-2.62)}$ & $-0.03 * * *(-2.94)$ \\
Corrupt*Post*SOE & & $0.02 * * *(3.44)$ \\
Corrupt*SOE & & $0.01 *(1.89)$ \\
Post*SOE & & $0.01 * * *(2.91)$ \\
SOE & & $-0.02 * * *(-4.00)$ \\
Control variables in each regression include firm size, leverage, tangible assets, sales, free cash flow, Tobin's \\
Q, and industry fixed effects \\
Adjusted R square & & \\
Observations & 0.47 & 0.47 \\
\hline
\end{tabular}

In the investment efficiency regression, we noted the measurement error when we used Tobin's $\mathrm{Q}$ as the proxy for investment opportunities; we now conduct two alternative specifications to check the robustness of our main results. Firstly, we follow the method used by Bushman et al. (2011) and Zheng and Zhu (2013), and use the sensitivity of investment growth to the change in investment opportunities (marginal Q) to measure investment efficiency. In particular, marginal Q is measured by the log of one plus lagged industry stock returns. Using industry stock returns can allow us to eliminate the influence of time-invariant variables at the firm level, and industry stock returns are less likely to be determined by firmspecific factors. Secondly, we use the high-order moment estimator, proposed by Robert and Whited (2012), to remedy the measurement error. We report the results estimated based on the information contained in the fifth-order moments, in Table 10. To save space, we only report the results for key variables.

Table 10.

The effect of political connections on investment efficiency (robustness tests)

This table presents the regression results on the effect of political connections on corporate investment efficiency. Quarterly observations for the event firms from three years before to three years after the event of corruption are applied in the regressions. The dependent variables are corporate investment growth in Panel A and investment expenditure in Panel B. RET is measured as the log of one plus lagged industry stock returns. All the other variables are defined as in Table 2. In Panel A, T-statistics are in parentheses, computed using the robust standard error clustered by the firm. In Panel B, Z-statistics are in parentheses. *, ** and *** indicate significance at the $10 \%, 5 \%$ and $1 \%$ levels, respectively.

\begin{tabular}{|c|c|c|c|}
\hline & Full sample & SOEs & Non-SOEs \\
\hline \multicolumn{4}{|c|}{ Panel A: Bushman et al. (2011) industry stock return method } \\
\hline Corrupt*RET & $0.25(1.09)$ & $0.39(1.38)$ & $0.19(0.55)$ \\
\hline Post*RET & $0.25(1.19)$ & $0.34 * *(2.40)$ & $-0.19 *(-1.84)$ \\
\hline Corrupt*Post*RET & $0.04(1.48)$ & $0.07 * *(2.00)$ & $-0.03 * * *(-2.58)$ \\
\hline \multicolumn{4}{|c|}{$\begin{array}{l}\text { Control variables in each regression include firm size, leverage, tangible assets, sales, free cash flow, and } \\
\text { quarter and industry fixed effects }\end{array}$} \\
\hline Adjusted R square & 0.47 & 0.24 & 0.52 \\
\hline Observations & 4522 & 2128 & 2394 \\
\hline
\end{tabular}




\begin{tabular}{|c|c|c|c|}
\hline Corrupt*Q & $0.03 *(1.71)$ & $-0.02(-1.01)$ & $0.08 * * *(2.74)$ \\
\hline Post*Q $\mathrm{Q}$ & $0.03(1.49)$ & $0.04 *(1.79)$ & $-0.02 *(-1.77)$ \\
\hline Corrupt*Post*Q & $0.04(1.30)$ & $0.12 * *(4.60)$ & $-0.01 * * *(-2.60)$ \\
\hline \multicolumn{4}{|c|}{$\begin{array}{l}\text { Control variables in each regression include firm size, leverage, tangible assets, sales, free cash flow and quarter } \\
\text { and industry fixed effects. Other interaction terms between each pair of our interest variables are also included } \\
\text { in each regression. }\end{array}$} \\
\hline Rho square & 0.45 & 0.22 & 0.49 \\
\hline Observations & 4522 & 2128 & 2394 \\
\hline
\end{tabular}

\subsection{Influence of the recent anti-corruption campaign}

We have proved that event firms experience significant changes in investment decisions (both investment expenditures and investment efficiency) relative to non-event firms. Our focus now will be the difference in the change in corporate investment decisions for event firms before and after the recent anti-corruption campaign that began after the conclusion of the $18^{\text {th }}$ Congress Conference at the end of 2012. Empirically, we re-estimate our previous regressions for the event firm sample only by replacing the variable Corrupt with Campaign, which is defined as a dummy variable equal to 1 for the post anti-corruption period, and 0 before, and report the results in Table 11. An interaction term between Post and Campaign is also included to test $\mathrm{H} 3$, the difference in investment decision changes before and after the anti-corruption campaign.

Panel A presents the results of the investment expenditure regression. Consistent with our results reported in Table 5, we observe that the average investment expenditure decreases after the corruption events, reflected by the statistically negative coefficients on Post across three specifications. Our concern is the coefficients on the interaction terms, which are negative across all specifications and statistically significant for the full sample and nonSOEs. This indicates that, after the ousting of corrupt officers, event firms experience a significant decline in investment expenditures compared with non-event firms, which was especially so after the anti-corruption campaign, and that this phenomenon is more pronounced for non-SOEs, which is consistent with our hypothesis H3. Panel B presents the results of the investment efficiency regression. As can be seen from columns 2 and 3 for both SOE and non-SOE subsamples, the estimated coefficients of Campaign $* P o s t^{*} Q$ are positive for SOEs and negative for non-SOEs (t-values are 2.13 and -1.78 , respectively). This is consistent with our broad expectation that the influence of the recent anti-corruption campaign has been more effective in bringing back overall investment efficiency in SOEs, while decreasing investment efficiency in non-SOEs. The signs of these two coefficients for both SOEs and non-SOEs are also consistent with those reported in Table 6, confirming the roles of sanding and greasing the wheel that corruption has played in SOEs and non-SOEs, 
respectively. These results are consistent with our predictions that the boldest and most serious anti-corruption campaign has imposed a more effective influence on firms' investment decisions.

\section{Table 11}

The effect of political connections on corporate investment decisions around the anti-corruption campaign for the event firm sample

This table presents the regression results for comparing the influence of political connections on corporate investment decisions before and after the anti-corruption campaign. Quarterly observations for the event firms from three years before to three years after the event of corruption are applied in the regressions. Campaign is a dummy variable, equal to 1 for observations after the anti-corruption campaign, and 0 otherwise. All the other variables are defined as in Table 2. T-statistics are in parentheses, computed using the robust standard error clustered by the firm. *, **and *** indicate significance at the $10 \%, 5 \%$ and $1 \%$ levels, respectively.

\begin{tabular}{|c|c|c|c|}
\hline & Full sample & SOE sample & Non-SOE sample \\
\hline \multicolumn{4}{|c|}{ Panel A: Investment expenditure regression } \\
\hline Campaign & $-0.06 * * *(-2.79)$ & $-0.03(-1.42)$ & $-0.08 * *(-2.14)$ \\
\hline Campaign*Post & $-0.07 * * *(-2.71)$ & $-0.03(-1.40)$ & $-0.10 * *(-2.17)$ \\
\hline Post & $-0.06 * * *(-3.43)$ & $-0.06 * * *(-3.05)$ & $-0.06 * *(-2.44)$ \\
\hline \multicolumn{4}{|c|}{$\begin{array}{l}\text { Control variables in each regression include firm size, leverage, tangible assets, sales, free cash flow, Tobin's Q, } \\
\text { and industry and quarter fixed effects }\end{array}$} \\
\hline Chow test & & $2.85^{*}$ & \\
\hline Adjusted R square & 0.37 & 0.23 & 0.43 \\
\hline Observations & 2261 & 1064 & 1197 \\
\hline \multicolumn{4}{|c|}{ Panel B: Investment efficiency regression } \\
\hline Campaign & $-0.07 *(-1.88)$ & $-0.07(-1.27)$ & $-0.03 * *(-2.03)$ \\
\hline Campaign*Q & $-0.05(-1.39)$ & $0.07(1.41)$ & $-0.08(-1.56)$ \\
\hline Campaign*Post*Q & $0.05(1.25)$ & $0.04 * *(2.13)$ & $-0.05 *(-1.78)$ \\
\hline Q & $0.01 * *(2.04)$ & $0.02 * *(2.44)$ & $0.07 * *(2.16)$ \\
\hline \multicolumn{4}{|c|}{$\begin{array}{l}\text { Control variables in each regression include firm size, leverage, tangible assets, sales, free cash flow and } \\
\text { industry and quarter fixed effects. Other interaction terms between each pair of our interest variables are also } \\
\text { included in each regression }\end{array}$} \\
\hline Chow test & & $7.37 * * *$ & \\
\hline Adjusted R square & 0.41 & 0.26 & 0.44 \\
\hline Over identification test & 0.44 & 0.48 & 0.34 \\
\hline Observations & 2261 & 1064 & 1197 \\
\hline
\end{tabular}

In addition to the previous tests, we also conduct some analyses to provide additional evidence to support our main hypotheses. Firstly, our main results suggest that political connections formed through corruption affect firms' investment decisions, so it is natural to expect that the influence of political connections is more pronounced in regions where corruption is more severe. Moreover, as argued before, the termination of political connections can mitigate the agency problems in SOEs and thus are beneficial for SOEs, but remove the benefits for non-SOEs, so we provide further evidence to support our arguments. Empirically, we examine whether, after the ousting of politicians, firm performance improves in event SOEs while it decreases in event non-SOEs, and whether stock market response is positive for event SOEs and negative for event non-SOEs. We also use both perquisites and CEO pay-performance relationship as proxies for the agency problem, and examine the changes in these two proxies after the ousting of politicians. 
The overall results of these tests show that the influence of political connection terminations on firm investment decisions is more pronounced in regions where corruption is more severe. They also show that, after the ousting of politicians, the event SOEs (non-SOEs) experience an improved (decreased) firm performance and positive (negative) stock market reactions. Moreover, perquisites decrease and pay-performance relationship becomes stronger for event SOEs, while event non-SOEs do not exhibit such significant change. These results further support our arguments and the main hypotheses. The detailed discussions and empirical results of these tests are presented in Appendix A.

\section{Conclusion}

Political capital and its economic implications have attracted much attention worldwide. In this study, we take advantage of corruption scandals in China to examine how political capital established through corruption shapes corporate investment decisions. In a departure from most existing cross-sectional studies, our study uses a natural experiment to avoid the endogeneity issue and clearly identify the causal effect of political capital on firm investment behaviours. Our sample includes all listed firms connected with high-level corrupt government bureaucrats through bribery or personal relationships, and their matching firms.

Consistent with our predictions, we find that investment expenditures decrease significantly, and that this is more pronounced for event non-SOEs following the arrest of the corrupt bureaucrats. We also find that investment efficiency is increased for event SOEs and reduced for event non-SOEs, relative to their non-event counterparties. We also observe that the above-mentioned change in investment decisions becomes more pronounced, for bribing firms, after the recent anti-corruption campaign or in more corrupt regions. Our additional analysis confirms the role played by the termination of political connections. In particular, we find that firm performance has recovered for event SOEs and deteriorated for event nonSOEs. Consistently, investors respond positively towards corruption cases for event SOEs, while negatively for event non-SOEs. We also document that perks are reduced significantly, and the executive pay-performance relationship becomes stronger, following the ousting of corrupt officials, and that the magnitude of these changes has been amplified after the initiation of the recent anti-corruption campaign, which applies particularly to SOEs.

Overall, our results reveal that political capital obtained through corruption may 'sand the wheel' of growth in SOEs, due to the fact that corruption may create potential collusion between SOE managers and government officers to extract private benefits for both of them; and that the recent anti-corruption campaign has effectively constrained the self-dealing behaviours of SOE managers, reflected by an improvement in investment efficiency and firm 
performance. However, corruption can be beneficial for non-SOEs, being used as the 'grease money' in exchange for government protection and good government service. Therefore, the recent anti-corruption campaign has broken this pattern and deteriorated investment efficiency, as well as performance, for non-SOEs.

Therefore, we argue that the success of the anti-corruption depends largely on the improvement of the legal and institutional environments. Our study has some useful implications for policy makers. On the one hand, it is desirable that a stronger institutional and legal system be established to shape SOE manager behaviours effectively. On the other hand, government might be encouraged to relinquish its control over the creation and allocation of economic rents, which will eliminate the ideological discrimination against nonSOEs. These will interactively reduce or even eliminate the incentives for both SOEs and non-SOEs to be involved in institutional corruption. 


\section{Appendix A}

\section{A1. Influence of political connections on investment decisions across regions}

In this section, we examine the influence of cross-sectional variations of corruption on investment decisions, by exploring firms' geographic locations. As our main finding from the previous analysis is that corruption distorts firms' investment decisions, it is natural to expect that this phenomenon is more pronounced in regions where corruption is more severe. To test our conjecture, we first construct a regional corruption index ${ }^{7}$, and divide all regions into two groups, in which the regional corruption index is above and below the median level of the corruption index for a given year. Then, we divide our sample firms into two groups located in more and less corrupt regions, and re-estimate investment expenditures and efficiency regressions for each subsample.

Table A1 reports the estimation results of our key variables. Panels A and B report both investment expenditures and investment efficiency regressions, respectively. In Panel A, the coefficient of Corrupt*Post is negative and statistically significant for the more corrupt region sample, while it is insignificant for the less corrupt region sample; indicating that event firms in more corrupt regions experience a significant decline in investment expenditures after the termination of political connections. In Panel $\mathrm{B}$, the interaction term Corrupt $* \operatorname{Post}^{*} Q$ shows a positive and significant coefficient for the more corrupt region sample only, indicating that event firms in more corrupt regions experience a significant improvement in investment efficiency after the termination of political connections. These results are broadly consistent with our expectations that corruption shows a more significant influence on firms' investment decisions if firms are located in regions where corruption is more severe.

\section{Table A1}

The effect of political connections on corporate investment decisions in more and less corrupt regions

This table presents the regression results for comparing the influence of political connections on corporate investment decisions between more and less corrupt regions. Quarterly observations from three years before to three years after the event of corruption are applied in the regressions. All the variables are defined as in Table 2. T-statistics are in parentheses, computed using the robust standard error clustered by the firm. *,**and *** indicate significance at the $10 \%, 5 \%$ and $1 \%$ levels, respectively.

\begin{tabular}{|c|c|c|}
\hline & More corruption regions & Less corruption regions \\
\hline \multicolumn{3}{|c|}{ Panel A: Investment expenditure regression } \\
\hline Corrupt & $0.05 *(1.64)$ & $0.05(0.52)$ \\
\hline Post & $-0.14 * * *(-4.96)$ & $-0.12 * *(-2.26)$ \\
\hline Corrupt*Post & $-0.11 * * *(-2.92)$ & $-0.10(-1.00)$ \\
\hline
\end{tabular}

\footnotetext{
${ }^{7}$ To construct a regional corruption index, we collect the following information for each province in each year during our sample from the China Procuratorial Yearbook: (1) the number of duty crime cases, (2) the number of government officials involved in these cases, and (3) the total number of government officials. Then, we calculate the corruption index as the ratio of (2) to (3) for each province in each year, which measures the number of government officials that are arrested per capita.
} 


\begin{tabular}{|c|c|c|}
\hline \multicolumn{3}{|c|}{ Control variables from investment expenditures are also included in each regression } \\
\hline Chow test & $4.45^{* *}$ & \\
\hline Adjusted R square & 0.42 & 0.46 \\
\hline Observations & 2261 & 2261 \\
\hline \multicolumn{3}{|c|}{ Panel B: Investment efficiency regression } \\
\hline Corrupt*Q & $0.02(0.22)$ & $-0.01(-0.35)$ \\
\hline Post*Q & $-0.08 *(-1.82)$ & $0.08(0.98)$ \\
\hline Corrupt*Post*Q & $0.13 * * *(2.58)$ & $-0.01(-1.41)$ \\
\hline \multicolumn{3}{|c|}{$\begin{array}{l}\text { Corrupt, Post and their interaction term, as well as other control variables from investment efficiency are also } \\
\text { included in each regression }\end{array}$} \\
\hline Chow test & $4.23 * *$ & \\
\hline Adjusted R square & 0.43 & 0.51 \\
\hline Over identification test & 0.33 & 0.38 \\
\hline Observations & 2261 & 2261 \\
\hline
\end{tabular}

\section{A2. Political connections and firm performance}

Firms' investment decisions can significantly influence firm performance, because firm performance responds positively to better investment, and gains from investment enhance firm profitability (Chen et al., 2009). To complement our main argument, in this section we examine whether changes in investment decisions are associated with changes in firm performance. We use the pre-event performance as a benchmark to evaluate firms' post-event performance and the changes in firm performance before and after the corruption events. Empirically, we apply the return on assets (ROA) as the proxy for performance, and we regress ROA against variables of our interest and a set of control variables, and report the results in Table A2.

As can be seen, the estimated coefficient on Corrupt is negative and significant at the 5\% level for the full sample and SOE sample, indicating that corruption incurs potential costs that will reduce firm performance. In relation to the Post, we find that they are negatively related to firm performance, suggesting that average firm performance declines after the corruption events. The interaction term is our main concern. In particular, for the full sample in column 1 , we find that the interaction term is positive, indicating that the average decline in firm performance is lower for event firms relative to non-event firms. When we split our total sample into both SOEs and non-SOEs, we find some further supportive evidence. For the SOE sample, the average firm performance increases $(-0.02+0.07=0.05)$ for event firms relative to non-event firms after the ousting of corrupt officers, indicating that corruption reduces firm performance for SOEs. For the non-SOE sample, the interaction term Corrupt*Post shows a negative and statistically significant coefficient (t-value is -2.35), indicating that, after the corruption events, the performance of non-SOE event firms experiences a more significant decline, relative to non-event non-SOEs. The overall results 
are consistent with our main argument, and provide supportive evidence for the hypothesis $\mathrm{H} 2$ that corruption sands the wheel in SOEs and greases the wheel in non-SOEs.

\section{Table A2}

The effect of political connections on firm performance

This table presents the regression results on the effect of political connections on firm performance. Quarterly observations for the event firms and control firms from three years before to three years after the event of corruption are applied in the regressions. The dependent variable is return on assets, defined as the ratio of net income to total assets. Corrupt is a dummy variable, equal to 1 for firms bribing government officers or connected with the corrupt government officers, and 0 otherwise. Post is a dummy variable, equal to 1 for observations of post-event period, and 0 otherwise. All the other variables are defined as in previous tables.

T-statistics are in parentheses, computed using the robust standard error clustered by the firm. *, **and *** indicate significance at the $10 \%, 5 \%$ and $1 \%$ levels, respectively.

\begin{tabular}{|c|c|c|c|}
\hline \multicolumn{4}{|c|}{ Dependent variable is return on assets (ROA) } \\
\hline & Full sample & SOE sample & Non-SOE sample \\
\hline Corrupt & $-0.05 * *(-2.03)$ & $-0.05 * *(-2.18)$ & $0.02(0.62)$ \\
\hline Post & $-0.03 *(-1.75)$ & $-0.02 *(-1.94)$ & $-0.05(-1.47)$ \\
\hline Corrupt*Post & $0.06(0.44)$ & $0.07 *(1.85)$ & $-0.02 * *(-2.35)$ \\
\hline \multicolumn{4}{|c|}{$\begin{array}{l}\text { Control variables in each regression include firm size, leverage, tangible assets, sales, free cash flow, Tobin's Q, } \\
\text { and industry and quarter fixed effects }\end{array}$} \\
\hline Chow test & & $3.90 * *$ & \\
\hline Adjusted R square & 0.26 & 0.26 & 0.28 \\
\hline Observations & 4522 & 2128 & 2394 \\
\hline
\end{tabular}

\section{A3. Political connections and cumulative abnormal returns}

In this section, we examine how investors react to the announcements of corruption events for event firms and non-event firms. This examination adds additional evidence to identify the effect of political connections in both SOEs and non-SOEs. In particular, the announcement effect is measured by the market-adjusted cumulative abnormal returns (CARs) around the corruption event announcements, using the market-adjusted excess return model. We choose a three-day event window (i.e. $-1,+1$ ), and 230 days as the estimation window (i.e. $-240,-10)$. The event day is defined as the first day when the corruption scandal was identified and announced to the public. For the regression analysis, we regress CARs against our key variables and control variables. Consistent with the method used by Claessens et al. (2008), the values of firm-level control variables are the average over our sample period.

As shown in Table A3, the coefficients on Corrupt are significantly negative for the full sample (column 1), indicating that, once corrupt officers have stepped down, the market value of connected firms is negatively affected. The estimated coefficient on Corrupt for nonSOEs is also negative and statistically significant at the $1 \%$ level (t-value is -5.63$)$, which is consistent with our expectation. However, some interesting results appear when we turn to the SOE samples. In particular, the coefficient on Corrupt is positive and statistically significant at the $5 \%$ level ( $\mathrm{t}$-value is 2.16 ), indicating that investors feel optimistic about the termination of political capital in SOEs. Although the general results are somewhat surprising, 
at least for SOEs, they are broadly consistent with our predictions that political capital obtained from corruption is detrimental for SOEs, but beneficial for non-SOEs.

\section{Table A3}

The effect of political connections on market reactions (CARs)

This table presents the regression results on the effect of political connections on CARs. The dependent variable is the three-day CARs around corruption event announcements. Corrupt is a dummy variable, equal to 1 for firms bribing government officers or connected with the corrupt government officers, and 0 otherwise. All the other variables are defined as in previous tables.

$\mathrm{T}$-statistics are in parentheses, computed using the robust standard error clustered by the firm. *, **and *** indicate significance at the $10 \%, 5 \%$ and $1 \%$ levels, respectively. Dependent variable is the CARs $(-1,+1)$ around corruption event announcements

\begin{tabular}{llll}
\hline & Full sample & SOE sample & Non-SOE sample \\
\hline Corrupt & $-0.10^{* *}(-2.49)$ & $0.03^{* *}(2.16)$ & $-0.22^{* * *}(-5.63)$ \\
Control variables in each regression include return & on sales, firm size, tangible assets, leverage, sales level, \\
free cash flow, Tobin's Q, industry fixed effects & & \\
Chow test & & $7.03^{* * *}$ & 0.14 \\
Adjusted R square & 0.09 & 0.07 & 116 \\
Observations & 220 & 104 & \\
\hline
\end{tabular}

It is possible that event firms may anticipate a decline in their market value due to the announcement of the corruption case, so that they may reinforce their political connections well before these announcements. Thus, our regression results may not really capture the effect of the termination of political connections. According to our previous discussion, that changes in political connection status may affect firm investment decisions, we expect to observe a significant difference in CARs between firms with and without political connections before those connections are terminated. To rule out this possibility, we conduct a placebo test by examining the CARs for the date immediately before the corruption case announcements. In particular, we redefine the event date as two days before the announcements of corruption events, and repeat our regression analysis in Table $\mathrm{A} 3^{8}$. The unreported results show that, for the full sample, SOE and non-SOE samples, the CARs of firms with political connections do not differ significantly from those of firms without political connections; and these results confirm our previous discussion.

\section{A4. Political connections and perks}

We have argued that, in SOEs, the incentives for pursuing private benefits motivate potential collusion between corrupt government officials and SOE managers, which will ultimately reduce investment efficiency. Furthermore, the private benefits extracted by SOE managers are likely to be in the form of perks (Gul et al., 2011), as their compensations are capped according to government policy (Hu et al., 2013). Consistent with our previous results, we conjecture that the amount of perks obtained by SOE managers will decline significantly

\footnotetext{
${ }^{8} \mathrm{We}$ thank the reviewer for pointing out this issue and suggesting this test.
} 
following the ousting of corrupt officials. In this section, we attempt to provide some direct evidence to verify our argument.

We follow Gul et al. (2011) to construct the amount of perks obtained. The perk data in this study is hand-collected from a particular item recorded in the notes of statements in firms' annual reports, called 'Other Cash Payments for the Expenses Related to Operating Activities'. Under this section, firms voluntarily disclose perk data from which six expense items are identified as constituting perks, namely travelling expenses, business entertainment expenses, overseas training expenses, board meeting expenses, company car expenses, and meeting expenses. Then, our perk variable is the sum of these six items scaled by firm sales. Due to the limitation of data availability, only annual perks are collected for empirical analysis.

Table A4 shows the regression results. In column 1 for the full sample, we observe that the estimated coefficient of Post is negative and statistically significant (t-value is -3.98), indicating that the amount of perks consumed has declined significantly after the corruption scandals. When we turn to both the SOE and non-SOE samples, we find that this negative coefficient is still significant for SOEs, while it has become insignificant for non-SOEs, which is consistent with our conjecture. We then observe that the estimated coefficient of Corrupt*Post is negative and statistically significant for SOEs (coefficient is -1.60 and tvalue is -2.15$)$, indicating that potential private benefits obtained by managers decreased significantly after the ousting of corrupt officials, and that the anti-corruption campaign is effective in curbing SOE managers' self-dealing behaviour. Overall, these results provide some direct evidence that, in SOEs, perks are actually the form of private benefits extracted by SOE managers, which motivates SOEs to boost investment activities with low efficiency. Once the ousting of corrupt officials occurs, investment efficiency will be rectified, due to constraints on the self-dealing behaviour of SOE managers and the amount of perks available. In non-SOEs, on the other hand, there is no significant change in perks, as managerial selfdealing behaviour is monitored by controlling shareholders, and thus the benefits obtained through political connections matter more for investment efficiency, as well as firm performance.

\section{Table A4}

The effect of political connections on perks

This table presents the regression results on the effect of political connections on perks. The dependent variable is the ratio of perks to sales. Corrupt is a dummy variable, equal to 1 for firms bribing government officers or connected with the corrupt government officers, and 0 otherwise. Post is a dummy variable, equal to 1 for observations of post-event period, and 0 otherwise. All the other variables are defined as in previous tables.

T-statistics are in parentheses, computed using the robust standard error clustered by the firm. *, **and *** indicate significance at the $10 \%, 5 \%$ and $1 \%$ levels, respectively. 


\begin{tabular}{|c|c|c|c|}
\hline \multicolumn{4}{|c|}{ Dependent variable is the ratio of perks to sales level } \\
\hline & Full sample & SOE sample & Non-SOE sample \\
\hline Corrupt & $0.63(1.00)$ & $2.14(1.16)$ & $0.14(0.18)$ \\
\hline Post & $-2.65 * * *(-3.98)$ & $-3.42 * * *(-3.41)$ & $-2.27(-1.53)$ \\
\hline Corrupt*Post & $-1.04(-1.12)$ & $-1.60 * *(-2.15)$ & $1.25(1.02)$ \\
\hline \multicolumn{4}{|c|}{$\begin{array}{l}\text { Control variables in each regression include return on assets, firm size, tangible assets, leverage, Tobin's Q, } \\
\text { industry and year fixed effects }\end{array}$} \\
\hline Chow test & & $3.05^{*}$ & \\
\hline Adjusted R square & 0.11 & 0.10 & 0.18 \\
\hline & 10 & 545 & 501 \\
\hline
\end{tabular}

\section{A5. Political connections and the pay-performance relationship}

As we have previously argued, the political connections established through bribery or personal relationships will exacerbate agency problems in SOEs, which will result in less efficient investment activities. In this section, we try to provide additional empirical evidence to show that the agency problem is mitigated once the political connections in SOEs are terminated. We focus on the relationship between managerial compensation and firm performance, as the proxy for the severity of the agency problem, because severe agency conflicts between managers and shareholders result from inadequate monitoring by shareholders, so that managers' compensation may be less likely to be closely linked to firm performance. Empirically, we regress the average compensation of the three most highly paid executives against firm performance and a set of control variables consistent with prior studies (Firth et al., 2006).

Table A5 reports the regression results, and our main focus is the interaction terms of ROA with other variables. In column 1 , the estimated coefficient on Corrupt ${ }^{*}$ Post $^{*} R O A$ is positive, indicating that the managerial pay-performance relationship becomes stronger following the corruption scandals, although the result is insignificant. Moreover, we find that this result becomes significant for SOEs (column 2), suggesting that, once the political connections between SOE managers and bureaucrats terminate, the SOE managers may face more monitoring by government officials, and the agency conflicts between managers and shareholders become weaker, which will enhance the link between managerial compensation and firm performance. In relation to ROA, we find that the estimated coefficients are positive and significant, which is consistent with previous studies (Firth et al., 2006). As for nonSOEs, we find no evidence that the pay-performance relationship has changed significantly since the termination of political connections. The proposed explanation for this insignificant change is that termination of political connections may only mitigate the agency problem between managers and shareholders; and, as the agency conflict between controlling shareholders and minority shareholders is more important in non-SOEs, the disciplinary 
power of controlling shareholders may not necessarily change, so that the influence of political connections is insignificant.

\section{Table A5}

The effect of political connections on the managerial pay-performance relationship

This table presents the regression results on the effect of political connections on the managerial payperformance relationship. The dependent variable is average compensation of top three paid executives. Corrupt is a dummy variable, equal to 1 for firms bribing government officers or connected with the corrupt government officers, and 0 otherwise. Post is a dummy variable, equal to 1 for observations of post-event period, and 0 otherwise. All the other variables are defined as in previous tables.

T-statistics are in parentheses, computed using the robust standard error clustered by the firm. *, **and *** indicate significance at the $10 \%, 5 \%$ and $1 \%$ levels, respectively.

\begin{tabular}{llll}
\hline \multicolumn{5}{l}{ Dependent variable is the log of average compensation of top three executives } \\
\hline \multicolumn{5}{l}{} & Full sample & SOE sample & Non-SOE sample \\
\hline Corrupt & $-0.65(-1.02)$ & $-1.91^{*}(-1.85)$ & $0.28(0.33)$ \\
Post & $-2.50^{* * *}(-3.75)$ & $-2.89^{* * *}(-2.68)$ & $-2.18^{* *(-2.39)}$ \\
Corrupt*Post & $1.07(1.16)$ & $1.54(1.08)$ & $1.01(0.81)$ \\
Corrupt*ROA & $0.97(0.43)$ & $0.45(0.05)$ & $-0.93(-0.32)$ \\
Post*ROA & $1.18(1.04)$ & $3.37(0.37)$ & $1.39(0.42)$ \\
Corrupt*Post*ROA & $2.41(0.85)$ & $3.44^{* *}(2.37)$ & $2.33(0.53)$ \\
ROA & $0.15^{* *}(2.16)$ & $5.03^{* * *}(2.57)$ & $0.06^{* *}(2.42)$ \\
Control variables in each & regression include firm size, tangible assets, leverage, Tobin's Q, board size, \\
proportion of independent directors, industry and year fixed effects & \\
Chow test & & $4.08^{* *}$ & \\
Adjusted R square & 0.15 & 0.13 & 0.16 \\
Observations & 1046 & 545 & 501 \\
\hline
\end{tabular}

\section{A6. Additional evidence from the recent anti-corruption campaign}

In Section 4.6, we documented that changes in investment and investment efficiency after the ousting of corrupt officials are more significant since the initiation of the recent anticorruption campaign in China. In the previous analyses in this Appendix, we have also provided additional evidence that the ousting of corrupt officials also results in a significant change in firm performance, perks and the pay-performance relationship; and we are thus more interested in examining whether these changes are more pronounced during the recent anti-corruption campaign period. In this subsection, we conduct a similar investigation to that in Table 11, to examine the difference before and after the initiation of the anti-corruption campaign, by focusing on the event firm sample.

Table A6 shows the regression results, and each panel represents each dependent variable of our interest, the main concern being the interaction term of Campaign with other variables in SOEs and non-SOEs. In Panel A, we find that the estimated coefficient of Campaign*Post is significantly positive for SOEs (column 2) and significantly negative for non-SOEs (column 3). These results suggest that firm performance increases for SOEs and decreases for non-SOEs after the corruption cases, and that the magnitude of these changes is amplified since the initiation of the anti-corruption campaign. The results in Panel B indicate that, for the post-anticorruption period, investors feel more optimistic towards the termination 
of political connections in SOEs, while more pessimistic in non-SOEs. Panel C and Panel D deal with changes in the entrenched agency problem. In particular, Panel C shows that the amount of perks consumed by managers has been reduced more in SOEs since the initiation of the anti-corruption campaign (reflected by the significantly negative coefficient of Campaign*Post in column 2), and Panel D indicates that the pay-performance relationship in SOEs becomes stronger for the post-anticorruption period (reflected by the significant positive coefficient of Campaign*Post*ROA in column 2). However, this may not necessarily be the case for non-SOEs. Overall, the results from Table A6 reflect that the recent anticorruption campaign has placed more substantial constraint on SOE managers' self-serving behaviour, and to some extent has caused the operational efficiency of SOEs to recover, which may be helpful to the whole Chinese economy and to social activities.

\section{Table A6}

The effect of political connections on performance, market reactions, perks and the pay-performance relationship around the anti-corruption campaign for the event firm sample

This table presents the regression results of comparing the influence of political connections on performance, market reactions, perks and the pay-performance relationship before and after the anti-corruption campaign. Quarterly observations for the event firms from three years before to three years after the event of corruption are applied in Panel A. Cross-sectional observations are applied for CAR regression (Panel B). Yearly data is applied for both Panel C and Panel D. Definitions of all variables are as in previous tables.

T-statistics are in parentheses, computed using the robust standard error clustered by the firm. *,**and *** indicate significance at the $10 \%, 5 \%$ and $1 \%$ levels, respectively.

\begin{tabular}{lccl}
\hline \multicolumn{2}{c}{ Full sample } & \multicolumn{1}{c}{ SOE sample } & \multicolumn{1}{c}{ Non-SOE sample } \\
\hline \multicolumn{2}{l}{ Panel A: Firm performance regression (Dependent variable is ROA) } & \\
\hline Campaign & $0.05^{*}(1.93)$ & $0.07 *(1.72)$ & $-0.04(-0.95)$ \\
Campaign*Post & $-0.03(-0.72)$ & $0.04 *(1.73)$ & $-0.10^{*}(-1.78)$ \\
Post & $-0.06^{* * *(-2.75)}$ & $0.02(0.69)$ & $-0.10^{* * *(-3.05)}$
\end{tabular}

Control variables in each regression include firm size, leverage, tangible assets, sales, free cash flow, Tobin's Q, and industry and quarter fixed effects

Chow test

Adjusted R square $\quad 0.20$

$0.20-0.22$

Observations $2261 \quad 1064$

$\begin{array}{ll}4.88^{* *} & \\ 0.22 & 0.28 \\ 1064 & 1197\end{array}$

\begin{tabular}{|c|c|c|c|}
\hline \multicolumn{4}{|c|}{ Panel B: Market reaction regression (Dependent variable is CARs) } \\
\hline Campaign & $-0.01(-0.37)$ & $0.04 * *(2.13)$ & $-0.05 * * *(-2.78)$ \\
\hline \multicolumn{4}{|c|}{$\begin{array}{l}\text { Control variables in each regression include firm size, leverage, tangible assets, sales, free cash flow, Tobin's Q, } \\
\text { and industry fixed effects }\end{array}$} \\
\hline Chow test & & $6.98 * * *$ & \\
\hline Adjusted R square & 0.15 & 0.13 & 0.15 \\
\hline Observations & 110 & 52 & 58 \\
\hline \multicolumn{4}{|c|}{ Panel C: Perks regression (Dependent variable is ratio of perks to sales) } \\
\hline Campaign & $-0.09(-0.78)$ & $-0.07(-0.86)$ & $-0.17(-0.83)$ \\
\hline Campaign*Post & $-0.71 * *(-2.18)$ & $-0.50 * *(-2.49)$ & $0.71(1.36)$ \\
\hline Post & $-0.09(-0.53)$ & $-0.12(-1.14)$ & $0.34(1.05)$ \\
\hline \multicolumn{4}{|c|}{$\begin{array}{l}\text { Control variables in each regression include return on assets, firm size, tangible assets, leverage, Tobin's Q, } \\
\text { industry and year fixed effects }\end{array}$} \\
\hline Chow test & & $5.12 * *$ & \\
\hline Adjusted R square & 0.12 & 0.16 & 0.13 \\
\hline Observations & 523 & 272 & 251 \\
\hline \multicolumn{4}{|c|}{ Panel D: Pay-performance regression (Dependent variable is the log of top three paid executives) } \\
\hline Campaign & $-0.07(-0.84)$ & $-0.08(-1.09)$ & $0.03(0.01)$ \\
\hline Campaign*ROA & $0.10(0.10)$ & $0.37 *(1.68)$ & $-0.02(-0.51)$ \\
\hline Campaign*Post*ROA & $0.07(1.42)$ & $0.15 * * *(3.04)$ & $0.06(1.17)$ \\
\hline
\end{tabular}




\begin{tabular}{|c|c|c|c|}
\hline \multirow{2}{*}{\multicolumn{4}{|c|}{ 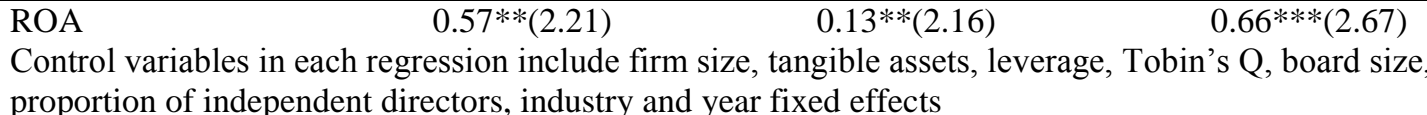 }} \\
\hline & & & \\
\hline Chow test & & $4.13 * *$ & \\
\hline Adjusted R square & 0.17 & 0.19 & 0.26 \\
\hline Observations & 523 & 272 & 251 \\
\hline
\end{tabular}




\section{References}

Aidt, T., Dutta, J., Sena, V., 2008. Governance regimes, corruption and growth: Theory and evidence. Journal of Comparative Economics 36, 195-220.

Aivazian, V., Ge, Y., Qiu, J., 2005. The impact of leverage on firm investment: Canadian evidence. Journal of Corporate Finance 11, 277-291.

Asiedu, E., Freeman, J., 2009. The effect of corruption on investment growth: Evidence from firms in Latin American, Sub-Saharan Africa, and Transition Countries. Review of Development Economics 13(2), 200-214.

Beck, T., Demirguc-Kunt, A., Levine, R., 2006. Bank supervision and corruption in lending. Journal of Monetary Economics 53, 2131-2163

Bliss, M., Gul, F., 2012. Political connection and cost of debt: Some Malaysian evidence. Journal of Banking and Finance 36, 1520-1527.

Boubakri, N., Cosset, J., Saffar, W., 2012. The impact of political connections on firms' operating performance and financing decisions. Journal of Financial Research 35(3), 397-423. Bushman, M. R., Piotroski, J. D., Smith, A. J., 2011. Capital allocation and timely accounting recognition of economic losses. Journal of Business Finance Accounting 38(1), 1-33.

Brandt, L., Li, H., 2003. Bank discrimination in transition economies: ideology, information, or incentives? Journal of Comparative Economics 31, 387-413.

Cai, H., Fang, H., Xu, L., 2011. Eat, drink, firms, government: an investigation of corruption from the entertainment and travel costs of Chinese firms. Journal of Law and Economics $54(1), 55-78$

Chen, G., Firth, M., Gao, D.N., Rui, O.M., 2006. Ownership structure, corporate governance, and fraud: Evidence from China. Journal of Corporate Finance 12 (3), 424-448.

Chen, G., Firth, M., Xu, L., 2009. Does the type of ownership control matter? Evidence from China's listed companies. Journal of Banking and Finance 33, 171-181.

Chen, C., Li, Z., Su, X., Sun, Z., 2011a. Rent-seeking incentives, corporate political connections, and the control structure of private firms: Chinese evidence. Journal of Corporate Finance 17(2), 229-243.

Chen, S., Sun, Z., Tang, S., Wu, D., 2011b. Government intervention and investment efficiency: Evidence from China. Journal of Corporate Finance 17, 259-271.

Chen, Y., Liu, M., Su, L., 2013. Greasing the wheels of bank lending: Evidence from private firms in China. Journal of Banking and Finance 37 (7), 2533-2545.

Claessens, S., Feijen, E., Laeven, L., 2008. Political connections and preferential access to finance: The role of campaign contributions. Journal of Financial Economics 88, 554-580. 
Cohen, J., 2015. Xi's crackdown on corruption has hit the obvious targets. The Financial Times. Access via: http://www.ft.com/intl/cms/s/0/32b90fd8-8129-11e4-b95600144feabdc0.html\#axzz3PzJ50vPd

Duchin, R., Ozbas, O., Sensoy, B., 2010. Costly external finance, corporate investment, and the subprime mortgage credit crisis. Journal of Financial Economics 97, 418-435.

Erickson, T., Whited, T., 2012. Treating measurement error in Tobin's Q. Review of Financial Studies 25, 1286-1329.

Faccio, M., 2010. Differences between politically connected and nonconnected firms: A cross-country analysis. Financial Management 39(3), 905-928.

Faccio, M., Parsley, D., 2009. Sudden deaths: Taking stock of geographic ties. Journal of Financial and Quantitative Analysis 44(3), 683-718.

Faccio, M., Masulis, R. W., McConnell, J. J., 2006. Political connections and corporate bailouts. Journal of Finance 61(6): 2597-2635.

Fan, J., Wong, T. J., Zhang, T., 2007. Politically connected CEOs, corporate governance, and post-IPO performance of China's newly partially privatized firms. Journal of Financial Economics, 84(2), 330-357.

Fan, J., Rui, O., Zhao, M., 2008. Public governance and corporate finance: Evidence from corruption cases. Journal of Comparative Economics 36, 343-364.

Fan, C. S., Lin, C., Treisman, D., 2009. Political decentralization and corruption: Evidence from around the world. Journal of Public Economics 93, 14-34.

Fazzari, S.M., Hubbard, R.G., Petersen, B.C., 1988. Financial constraints and corporate investment. Brookings Paper. Economic Act 1, 141-206.

Feng, X., Johanson, A., Zhang, T., 2015. Mixing business with politics: political participation by entrepreneurs in China. Journal of Banking and Finance 59, 220-235.

Firth, M., Fung, P., Rui, O., 2006. Corporate performance and CEO compensation in China. Journal of Corporate Finance 12, 693-714.

Firth, M., Lin, C., Wong, S. M. L., 2008. Leverage and investment under a state-owned bank lending environment: Evidence from China. Journal of Corporate Finance 14, 642-653.

Firth, M., Malatesta, P. H., Xin, Q., Xu, L., 2012. Corporate investment, government control, and financing channels: Evidence from China's listed companies. Journal of Corporate Finance 18, 433-450.

Gaviria, A., 2002. Assessing the effects of corruption and crime on firm performance: evidence from Latin America. Emerging Markets Review 3, 245-268. 
Goldman, E., Rocholl, J., So, J., 2009. Do politically connected boards affect firm value? Review of Financial Studies 22(6), 2231-2360.

Gul, F., Cheng, L., Leung, T.Y., 2011. Perks and the informativeness of stock prices in the Chinese market. Journal of Corporate Finance 17, 1410-1429.

Houston, J. F., Lin, C., Ma, Y., 2011. Media ownership, concentration and corruption in bank lending. Journal of Financial Economics 100, 326-350.

Houston, J., Jiang, L., Lin, C., Ma, Y., 2014. Political connections and the cost of bank loans. Journal of Accounting Research 52(1), 193-243.

Hu, F., Pan, X., Tian, G., 2013. Does CEO pay dispersion matter in an emerging market? Evidence from China's listed firms. Pacific-Basin Finance Journal 24, 235-255.

Hung, M., Wong, T.J., Zhang, F., 2015. The value of political ties versus market credibility: Evidence from corporate scandals in China. Working paper.

Kim, C., Pantzalis, C., Park, J., 2012. Political geography and stock returns: The value and risk implications of proximity to political power. Journal of Financial Economics 106, 196228.

La Porta, R., Lopez-de-Silanes, F., Pop-Eleches, C., Shleifer, A., 2004. Judicial checks and balances. Journal of Political Economy 112, 445-470.

Lang, L., Ofek, E., Stulz, R., 1996. Leverage, investment, and firm growth. Journal of Financial Economics 40, 3-29.

Leuz, C., Oberholzer-Gee, F., 2006. Political relationships, global financing, and corporate transparency: Evidence from Indonesia. Journal of Financial Economics 81(2), 411-439.

Li, H. B., Meng, L. S., Wang, Q., Zhou L. A., 2008. Political connections, financing and firm performance: Evidence from Chinese private firms. Journal of Development Economics 87(2): 283-299.

Li, H., Zhou, L., 2005. Political turnover and economic performance: the incentive role of personnel control in China. Journal of Public Economics 89, 1743-1762.

Mauro, P., 1995. Corruption and growth. The Quarterly Journal of Economics 110(3), 681712.

Lin, C., Morck, R., Yeung, B., Zhao, X., 2016. Anti-corruption reforms and shareholder valuations: Evidence from China. Working paper.

Meon, P.G., Sekkat, K., 2005. Does corruption grease or sand the wheels of growth? Public Choince122(1-2), 69-97.

Meon, P.G., Weill, L., 2010. Is corruption an efficient grease? World Development 38(3), 244-259. 
Morck, R., Wolfenzon, D., Yeung, B., 2005. Corporate governance, economic entrenchment, and growth. Journal of Economic Literature 43(3), 655-720.

Myers, S., 1977. Determinants of corporate borrowing. Journal of Financial Economics 5, $147-175$.

Ngo, T., 2008. Rent-seeking and economic governance in the structural nexus of corruption in China. Crime, Law and Social Change 49, 27-44

People's Daily, 17 November 2012. Access viahttp://news.xinhuanet.com/201211/19/c_123967017.htm

Piotroski, J., Zhang, T., 2014. Politicians and the IPO decision: The impact of impending political promotions on IPO activity in China. Journal of Financial Economics 111, 111-136.

Robert, M., Whited, T., 2012. Endogeneity in empirical corporate finance. SSRN working paper.

Shleifer, A., Vishny, R. W., 1993. Corruption. The Quarterly Journal of Economics 108(3), 599-617.

Stulz, R.M., 1990. Managerial discretion and optimal financing policies. Journal of Financial Economics 26, 3-27.

Wang, Y., You, J., 2012. Corruption and firm growth: Evidence from China. China Economic Review 23(2), 415-433.

Wu, W., Wu, C., Rui, M., 2012. Ownership and the value of political connections: Evidence from China. European Financial Management 18(4), 695-729.

Xu, N., Xu, X., Yuan, Q., 2011. Political connections, financing friction, and corporate investment: Evidence from Chinese listed family firms. European Financial Management 19(4), 675-702.

Zheng, Y., Zhu, Y., 2013. Bank lending incentives and firm investment decisions in China. Journal of Multinational Financial Management 23, 146-165. 